\title{
Nerve Growth Factor (NGF)-Receptor Survival Axis in Head and Neck Squamous Cell Carcinoma
}

\author{
József Dudás * (D), Wolfgang Dietl, Angela Romani, Susanne Reinold, Rudolf Glueckert, \\ Anneliese Schrott-Fischer, Daniel Dejaco, Lejo Johnson Chacko ${ }^{\mathbb{D}}$, Raphaela Tuertscher, \\ Volker Hans Schartinger and Herbert Riechelmann \\ Department of Otorhinolaryngology, Medical University of Innsbruck, Anichstrasse 35, \\ A-6020 Innsbruck, Austria; wolfgang.dietl@student.i-med.ac.at (W.D.); angela.romani@i-med.ac.at (A.R.); \\ susanne.reinold@i-med.ac.at (S.R.); rudolf.glueckert@i-med.ac.at (R.G.); annelies.schrott@i-med.ac.at (A.S.-F.); \\ daniel.dejaco@i-med.ac.at (D.D.); lejo.johnson@student.i-med.ac.at (L.J.C.); raphaela111@gmx.net (R.T.); \\ volker.schartinger@i-med.ac.at (V.H.S.); herbert.riechelmann@i-med.ac.at (H.R.) \\ * Correspondence: jozsef.dudas@i-med.ac.at; Tel.: +43-512-504-82475; Fax: +43-512-504-23175
}

Received: 7 May 2018; Accepted: 12 June 2018; Published: 14 June 2018

\begin{abstract}
Neurotrophins and their receptors might regulate cell survival in head and neck squamous cell carcinoma (HNSCC). mRNA expression of nerve growth factor (NGF) and protein synthesis of high (NTRK1) and low affinity neurotrophin (p75 neurotrophin receptor; NTR) receptors were investigated in normal oral mucosa and in HNSCC. HNSCC cell lines were treated with mitomycin $\mathrm{C}$ (MMC) and cell survival was investigated. Normal and malignant epithelial cells expressed NGF mRNA. NTRK1 was upregulated in $80 \%$ of HNSCC tissue, and $50 \%$ of HNSCC samples were p75NTR positive. Interestingly, in HNSCC tissue: NTRK1 and p75NTR immunohistochemical reactions were mutually exclusive. Detroit 562 cell line contained only p75NTR, UPCI-SCC090 cells synthesized NTRK1 but not p75NTR and SCC-25 culture had p75NTR and NTRK1 in different cells. NGF (100 ng/mL) significantly improved (1.4-fold) the survival of cultured UPCI-SCC090 cells after MMC-induced cell cycle arrest, while Detroit 562 cells with high levels of p75NTR did not even get arrested by single short MMC treatment. p75NTR in HNSCC might be related with NGF-independent therapy resistance, while NTRK1 might transduce a survival signal of NGF and contribute in this way to improved tumor cell survival after cell cycle arrest.
\end{abstract}

Keywords: cytokeratin; necrosis; cell cycle arrest; TissueFaxs

\section{Introduction}

Neurotrophins are growth factors that play important roles in physiology of organ functions but also in pathologies such as major depressive disorder, neuropathic pain, heart failure, irritable bowel syndrome, autism or mental retardation. In children in the autistic spectrum and in those with mental retardation without autism, elevated levels of the neurotrophin brain-derived neurotrophic factor (BDNF) were measured [1]. The same neurotrophin, BDNF, showed abnormally low serum levels in major depressive disorder [2]. In another pathophysiological condition, in irritable bowel syndrome, BDNF also makes a significant contribution, since increased expression of BDNF in colonic mucosa, contributes to the visceral hyperalgesia [3]. The main function of neurotrophins is the support of neuron survival, which is exemplified by the myocardial produced nerve growth factor (NGF) that is involved in the maintenance of sympathetic neuronal survival [4]. A further very important function is the interaction of the endocannabinoid system and the neurotrophins BDNF and NGF in the control of neuropathic pain mechanisms [5]. Neurotrophins either bind to low affinity (Low-affinity Nerve Growth Factor (LNGFR)/p75 neurotrophin receptor 
(p75NTR)) receptor [6,7] or to the high affinity Trk (tropomyosin-related kinase) tyrosine kinase receptors. The Trk family (neurotrophin receptor tyrosine kinase, NTRK) of receptors include NTRK1 (NTRK1) specific for NGF [8], NTRK2 (TrkB) specific for BDNF and neurotrophin-4 (NT-4) [9], and NTRK3 (TrkC) which is also activated by NT-4 [10]. The knowledge on neurotrophins and neurotrophin receptors in head and neck squamous cell carcinoma (HNSCC) is scarce. In HNSCC, neurotrophins play a role in perineural growth, which is a unique route of tumor progression associated with poor prognosis [11]. Neurotrophins may serve as molecular factors involved in the communication between tumor and neuronal cells. Deriving from neuronal sources, they support survival, anti-apoptosis [12] and cell-detachment inducing migratory [12] effects. We [13-15] and others [16] previously suggested that BDNF stimulation of HNSCC cell lines upregulated migration and invasion. Furthermore, overexpression of NTRK2 in HNSCC tumor cells was related with epithelial-to-mesenchymal transition (EMT). In contrast, less is known about NTRK1 and its ligand NGF in HNSCC, which were reported as important survival factors for oral mucosa epithelial cells [17]. Recently Yamaguchi et al. [18] published that p75NTR ${ }^{+}$tumor cells are mitotically quiescent cancer stem cells. At the same time, p75NTR ${ }^{+}$chemoresistant stem cells $[18,19]$ shared some characteristics with epithelial-to-mesenchymal transdifferentiated cells [18]. In human adult oral mucosa lamina propria, p75NTR ${ }^{+}$stem cells are self-renewing cells [20]. NGF growth factor and its low affinity receptor p75NTR might be involved in pleiotropic, stem-cell-like effects as self-renewal and epithelia regeneration [21]. Accordingly, p75NTR has been published in undifferentiated cell populations of oral leukoplakia as well as in oral squamous cell carcinoma (OSCC), where it was associated with poor prognosis [22]. In fact, p75NTR is supposed to play a pro-tumoral role by contributing to drug resistance [23]. Based on intracellular adaptor molecule availability, and post-translational modifications, p75NTR might be involved in cell-fate decisions just by taking part in multiple signaling pathways [21].

HNSCC is among the seven most common malignancies worldwide. The development of HNSCC is related to tobacco use and alcohol consumption, as the most identified risk factors, but human papilloma virus (HPV), a sexually transmitted infection, has increasing significance as another primary cause of HNSCC [24]. HPV-positive tumors not only have a different etiology, but they also remarkably better respond to radio(chemo)therapy [25], as well as surgery [26], compared to HPV-negative tumors. Concluding, the HPV-positive patients have a better prognosis. In this work, we investigated the hypothesis that NGF and its high or low affinity receptors might elaborate a survival signaling pathway in HNSCC. Based on the clear etiological and therapy response differences in $\mathrm{HPV}^{+}$and $\mathrm{HPV}^{-} \mathrm{HNSCC}$ patients, we also compared the survival relation of NGF and its receptors in this two HNSCC patient groups and in related cell lines.

\section{Results}

2.1. Gene Expression of NGF and Protein Synthesis of NTRK1 and p75NTR in Oral Mucosa, HNSCC Tumor Tissue and in HNSCC Tumor Cell Lines

Using RNA isolation, reverse transcription, PCR and in situ hybridization (ISH), the mRNA expression of NGF, and using immunohistochemistry (IHC), the protein synthesis of NGF receptors, NTRK1 and p75NTR, were investigated in normal mucosa from uvulopalatopharyngoplasties (UPPP) in HNSCC tumor tissue and in HNSCC cell lines. The normal epithelium of UPPP (Figure 1A,C), HNSCC tumor cell lines (Figure 1A) and HNSCC tissue samples (Figure 1B) expressed various levels of NGF mRNA. Normal mucosa and HNSCC tissue samples included examples of high and low NGF gene expression, as well as different levels of housekeeping gene ACTB ( $\beta$-actin) (Figure 1A,B). Using ISH, we attempted to identify the source of NGF-producing cells in normal oral mucosa, and in HNSCC. In the normal mucosa, the epithelial cell compartment was the main source of the NGF mRNA, while the stroma had a low and sporadic expression (Figure 1C). In addition, a gradient of NGF was observed, presenting high reactivity in basal cells and lower intensity towards suprabasal cells (Figure 1C). These results have been also confirmed by fluorescent detection of the NGF ISH signal 
and by simultaneous immunohistochemical detection of cytokeratin (Figure 2A,B). In HSNCC tissue, ISH evidenced that the cancer cell nests (Figures 1D and 2C-F) were capable of NGF mRNA synthesis. Figure 2C-F presents a co-localization of the antisense NGF riboprobe and the pan-cytokeratin antibody in larynx and oral HNSCC tumor cell nests.

A

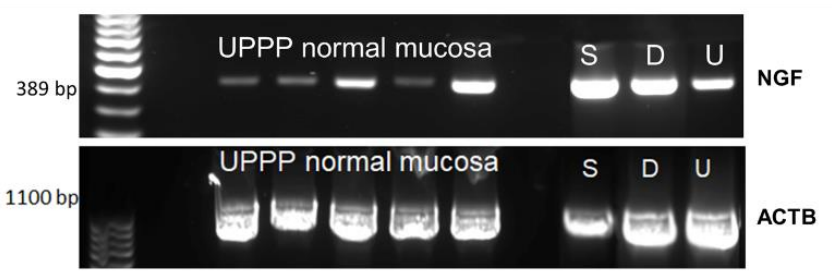

B
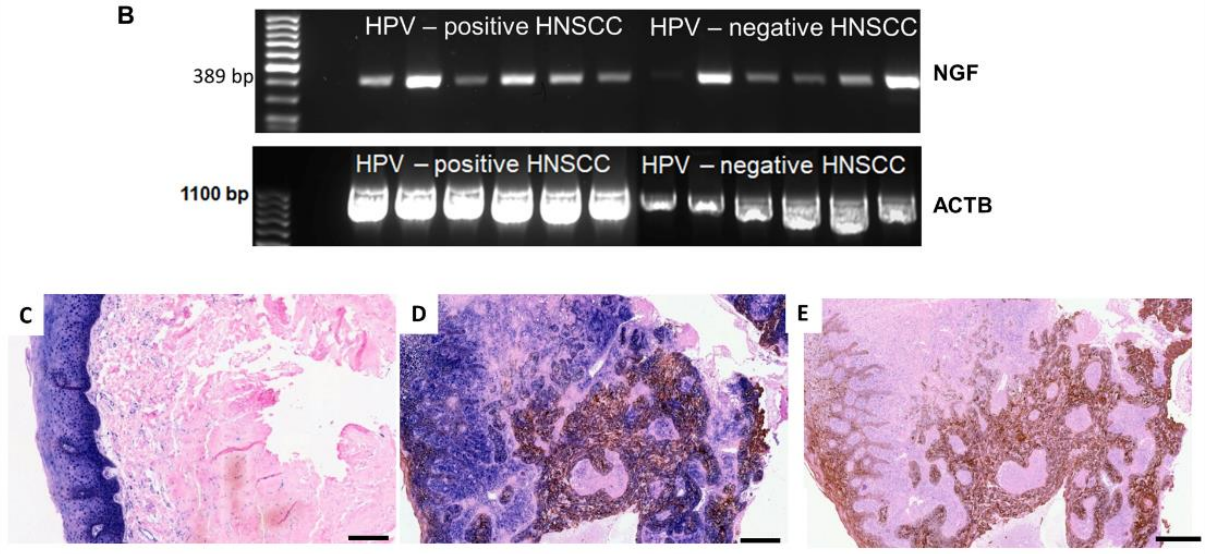

Figure 1. mRNA expression of nerve growth factor (NGF) and protein synthesis of NTRK1 in normal mucosa from uvulopalatopharyngoplasty (UPPP) and in HNSCC. (A) RT-PCR from reverse transcribed RNA representing a product of 389 base pairs of NGF and of 1100 base pairs of housekeeping gene $\beta$-actin (ACTB) in five samples of normal mucosa from UPPP and in SCC-25 (S), Detroit 562 (D) and UPCI-SCC090 (U) HNSCC cell lines. All mucosa samples contained various levels of NGF mRNA, HNSCC cell lines expressed high levels of NGF mRNA; (B) RT-PCR from reverse transcribed RNA representing a product of 389 base pairs of NGF and of 1100 base pairs of housekeeping gene ACTB in 6-6 samples of $\mathrm{HPV}^{+}$and $\mathrm{HPV}^{-}$HNSCC tumor tissue. All tumor samples contained various levels of NGF mRNA. In HPV-negative samples the housekeeping gene showed also variation; (C) Combined ISH of antisense riboprobe of NGF (blue) and immunohistochemistry of NTRK1 (brown) in normal mucosa from UPPP. No separate brown signal was visible because of the co-localisation of NGF and NTRK1 (dark, nearly black staining in the basal cells). In the basal cells, traces of brown color and black reaction represented both NGF and NTRK1 signals; (D) Combined ISH of NGF antisense riboprobe (blue) and IHC of NTRK1 (brown) in hypopharynx squamous cell carcinoma. Besides cells positive for both blue and brown signals, there were also separate brown and blue stained areas visible; (E) Combined ISH of control sense riboprobe (blue) and IHC of NTRK1 (brown) in hypopharynx squamous cell carcinoma. The control sense probe showed only a minimal blue background reaction. Images were taken by the TissueFaxs system, bars: $200 \mu \mathrm{m}$. Pink background on (C,D) is the colour of the counterstain, nuclear fast red (Red Counterstain of Ventana). The ISH was repeated on three sections of the tissue samples, a representative example is shown.

Similar to NGF, the high affinity NGF receptor, NTRK1 [27] was localized to the epithelial cell compartment of both normal epithelium and HNSCC (Figure 1C,D). In epithelium of UPPP, NTRK1 positive IHC reaction was limited to the basal cell layer (Figure 1C). In contrast, in HNSCC (Figure 1D,E) apparently all cells in the cancer cell nests were stained with NTRK1 antibody. No clear relation was found between the distribution pattern of NGF mRNA expression and NTRK1 protein synthesis. NTRK1 clearly co-localized with cytokeratin in established cancer cell nests as well as in small cytokeratin-positive groups of disseminating tumor cells (Appendix A; Figure A1). These results 
suggested an epithelial characteristic to both NGF mRNA expression and NTRK1 protein synthesis, which was obvious in the case of normal mucosa, and was further evidenced for HNSCC.

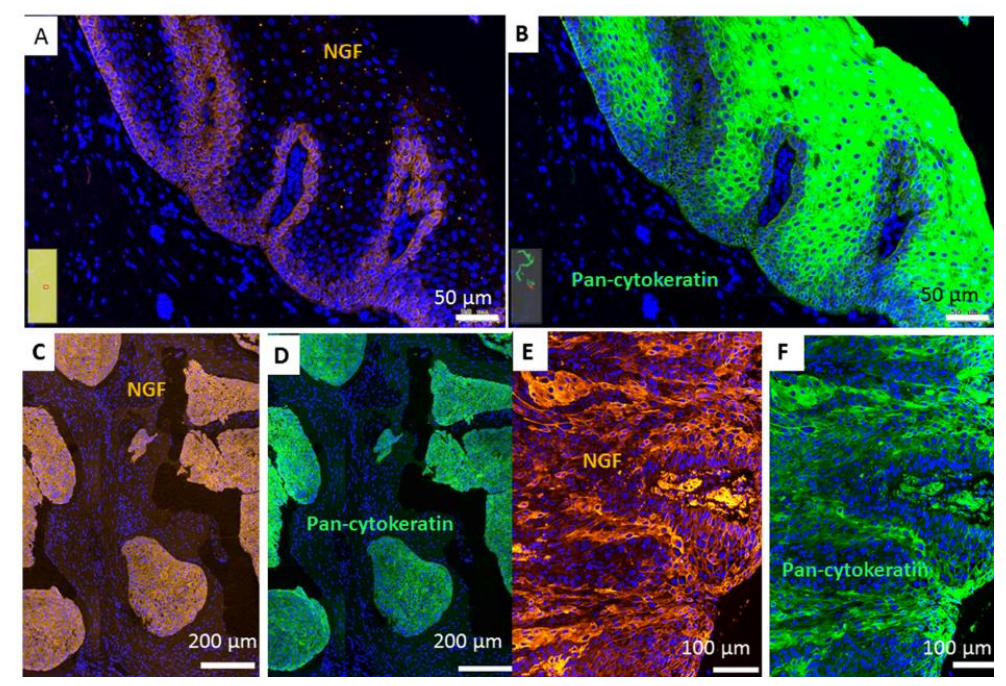

Figure 2. mRNA expression of NGF using a Digoxigenin-labeled antisense probe (NGF, orange or browndetected by anti-digoxigenin-rhodamin (A,C,E); and IHC of pan-cytokeratin (green, Alexa Fluor 488) (B,D,F) in normal mucosa from uvulopalatopharyngoplasty (UPPP; (A,B)), larynx (C,D) and oral (E,F) HNSCC. Images were taken by the TissueFaxs system; bars are indicated on the images. The cell nuclei in all sections were counterstained in DAPI (blue). The ISH was repeated on three sections of the tissue samples, a representative example is shown.

In contrast to NTRK1, which was broadly distributed (Figure 1D,E), about the half of the HNSCC cases did not synthesize p75NTR in their epithelial cancer cell nests (an example is visible in Figure 3A), whereas it was detected in stroma, or at the border of the cancer cell nests (Figure 3A,C). In few cases, 7 of 93 HNSCC, the opposite was found: a broad p75NTR staining in epithelial cancer cell nests (Figure 3B, green reaction), without NTRK1 staining. In cases where both NTRK1 and p75NTR were present, they were detected in mutually exclusive cells (Figure 3C-E), or the p75NTR-positive cells showed low NTRK1 reaction and vice versa (Figure 3F-H).
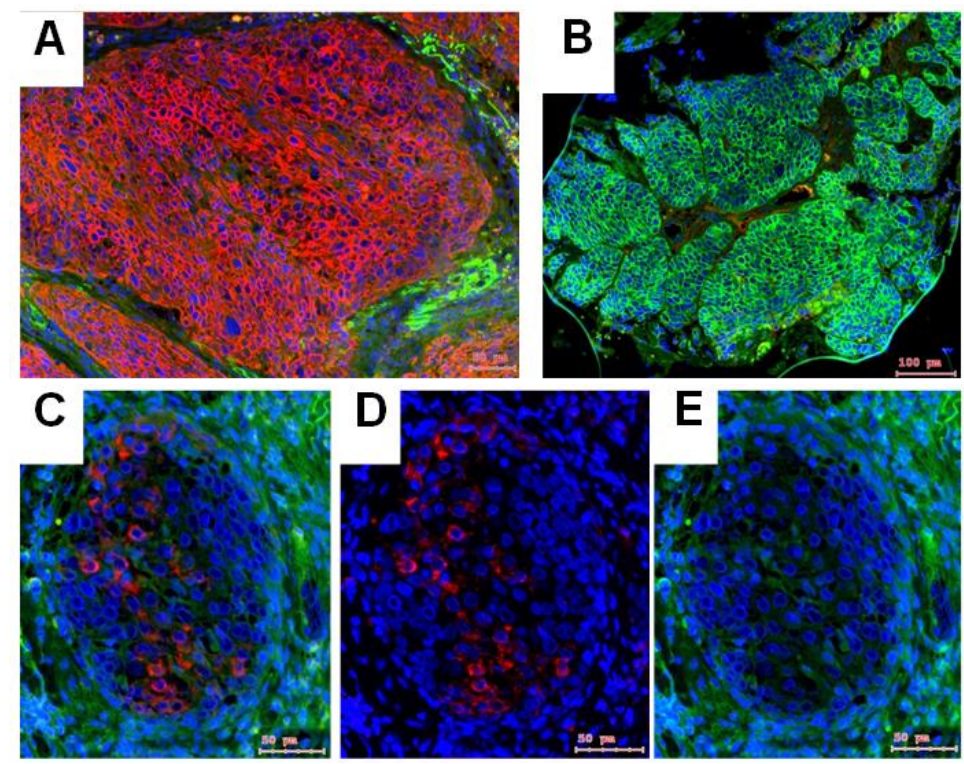

Figure 3. Cont. 


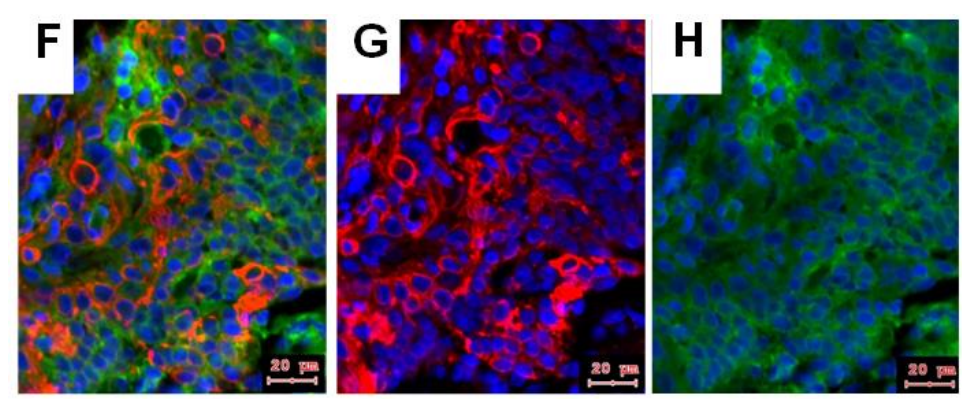

Figure 3. IHC staining of NTRK1 (red) and p75NTR (green) in HPV-positive (A,F-H) and HPV-negative (B,C-E) oropharynx squamous cell carcinoma (OSCC). (A) Combined IHC-staining of NTRK1 (red or orange on green background) and p75NTR (green) in an example of HPV-positive OSCC). In this sample NTRK1 staining was dominant in tumor cell nests and p75NTR was present only in stroma. (B) Combined IHC-staining of NTRK1 (red) and p75NTR (green) in an example of HPV-negative OSCC. In this sample, p75NTR-staining was detected in tumor cell nests without traces of NTRK1. (C-E) Combined (C) and separated IHC-staining of NTRK1 ((D), red) and p75NTR ((E), green) in an example of HPV-negative OSCC. In the tumor cell nests, NTRK1 and p75NTR were both present, but the positive cells were mutually exclusive. (F-H) Combined (F) and separated IHC-staining of NTRK1 $((\mathbf{G})$, red) and p75NTR $((\mathbf{H})$, green) in an example of HPV-positive OSCC. In the tumor cell nests NTRK1 and p75NTR were both present, but the NTRK1 positive cells showed weaker p75NTR staining. Images were taken by the TissueFaxs system, bars are indicated on the images. The cell nuclei in all sections were counterstained in DAPI (blue). Although the $\mathrm{HPV}^{+}$or $\mathrm{HPV}^{-}$nature of the cases are mentioned, the staining pattern is not necessarily related with the HPV carcinogenesis.

\subsection{NTRK1 and p75NTR NGF Receptors Synthesis Negative Correlate in HNSCC Tumor Specimens}

UPPP and HNSCC samples were immunohistochemically investigated for the high and low affinity NGF receptors. In the available 12 UPPP samples: five (41.6\%) showed positive reaction for NTRK1 and eight $(66.636 \%)$ showed positive reaction for p75NTR. The staining intensity of NTRK1 was weak, while in three UPPP cases the p75NTR staining intensity was high. Five UPPP samples showed positive reaction for both of NTRK1 and p75NTR, four UPPP samples had no staining of any of these NGF receptors. NTRK1 was not present in normal mucosa without p75NTR, while in three normal mucosa samples p75NTR was not accompanied by NTRK1.

Ninety-three HNSCC samples were available for NTRK1 and p75NTR IHC. Seventy-five of 93 (80.64\%) HNSCC showed positive reaction for NTRK1 and 48 of 93 (51.61\%) HNSCC showed positive reaction for p75NTR. Increased NTRK1 IHC (higher than the level of normal mucosa) was found in 73 of 93 cases $(78.50 \%$ ), whereas increased p75NTR IHC (at least 33\% of the cells in tumor cell nests positive) was found in 20 of 93 cases (21.50\%). Seven cases were negative for both of NTRK1 and p75NTR, 14 cases showed increased reaction for both of NTRK1 and p75NTR, 45 cases had only NTRK1 and no p75NTR, and 7 cases had only p75NTR and no NTRK1.

The NTRK1 IHC was significantly (Figure $4 \mathrm{~A}, p<10^{-4}$ ) higher in the cancer cell nests of HNSCC than in the normal epithelium of the UPPP samples. Neither NTRK1 nor p75NTR IHC showed any significant difference in any of the HNSCC localizations. In a sample of 14 HNSCC specimens containing both NTRK1 and p75NTR staining in the cancer cell nests, the staining intensity was evaluated by HistoQuest (Supplementary Information; Supplementary Methods). The values of p75NTR intensity were plotted on the $X$-axis and the ones of NTRK1 intensity on the $Y$-axis. p75NTR intensities were lower (Figure 4B). The relationship between $X-Y$ values was modeled by SPSS ${ }^{\mathrm{TM}}$ and a significant $(p=0.002)$ inverse relationship was found (Figure $4 \mathrm{~B})$. Correlation analysis by Spearman's rho showed a high significant $(p=0.005)$ negative correlation between p75NTR and NTRK1 intensity (correlation coefficient: -0.7 ). Taken the IHC results together, in HNSCC the NTRK1 staining was high in the majority of the tumor cell nests, the tumor cells were either stained for NTRK1 or for p75NTR, 
in the case if both receptors were present, the cells stained with p75NTR and the ones stained with NTRK1 were mutually exclusive.

A

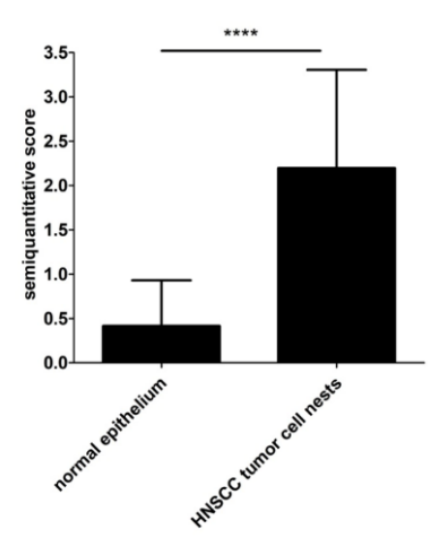

B

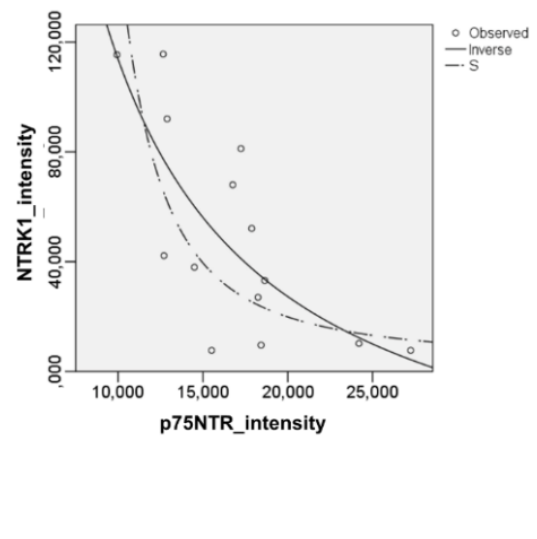

Figure 4. NTRK1 representation in UPPP and HNSCC specimens. (A) In a sample of 93 HNSCC and 12 UPPP specimens, the NTRK1 and p75NTR IHC intensity ranged no staining (0), low (score 1), middle (score 2) and high (score 3). The NTRK1 staining score was significantly (A) $\left(p<10^{-4 * * * *}\right)$ higher in the cancer cell nests of HNSCC than in the normal epithelium of the UPPP samples. (B) In a sample of 14 HNSCC specimens containing both NTRK1 and p75NTR staining in the cancer cell nests, the staining intensity was evaluated by HistoQuest (Supplementary Information, Supplementary Methods, Figures S1-S3). The values of p75NTR intensity were plotted on the X-axis and of NTRK1 intensity on the $Y$-axis. The p75NTR intensities were lower. The relationship between $X-Y$ values was modeled by SPSS ${ }^{\mathrm{TM}}$ and a significant $(p=0.002)$ inverse relationship was found.

\subsection{Patient Survival Relation of NTRK1 and p75NTR in Human Papilloma Virus (HPV) Positive and Negative HNSCC Cases}

As presented previously, both HPV-positive and -negative HNSCC tissues were capable of NGF-gene-expression (Figure 1B). HPV-positive cases were decided by IHC of the surrogate marker p $16^{\mathrm{INK} 4}$ being in at least $66 \%$ of the tumor cells positive. Taking HPV DNA PCR analysis as the reference method, the sensitivity of p16 IHC was $78 \%$ and the specificity was $79 \%$ [28]. The p16 ${ }^{\mathrm{INK} 4}$-based HPV evaluation was possible in 92/93 HNSCC cases. Twenty-eight cases were HPV-positive and 64 cases were HPV-negative. Overall, $84.37 \%$ of HPV-negative cases and $75 \%$ of HPV-positive cases showed increased NTRK1 staining. The staining intensity of NTRK1 in HPV-positive and -negative HNSCC did not differ significantly ( $p=0.147$ using Mann-Whitney test). In total, $53.12 \%$ of HPV-negative and $50 \%$ of HPV-positive cases were p75NTR-positive. The staining intensity in HPV-positive and -negative HNSCC did not differ significantly ( $p=0.9$ using Mann-Whitney test). The HPV carcinogenesis background did not show any relation with immunohistochemical detection of NGF receptors.

The NTRK1 and p75NTR staining levels were not related to significant patient survival effects in Kaplan-Meier censored case survival processing where Log Rank (Mantel-Cox) pairwise comparisons were performed (Appendix B; Table A1), if all cases were processed. Because of the strong beneficial survival influence of HPV-background [25,26], HPV-positive and -negative cases were also separately processed, to eliminate the major survival influence of the HPV background. Indeed, 90\% of HPV-positive patients with wild type TP53 survived two years after first contact, while 50\% HPV-negative patients with altered p53 were lost within two years after first contact (own unpublished data, Log Rank (Mantel-Cox) pairwise comparison; $p<10^{-3}$ ). The NTRK1 level or the p75NTR presence did not show any significant patient survival influence either in HPV-positive or negative HNSCC cases. In HPV-positive cases there was a visible, but not significant tendency for lower survival rate $(66.7 \%$ against $85.7 \%)$ and for shorter survival time (41 months against 62 months) if NTRK1 protein level was above the control normal tissue level. p75NTR presence or absence did 
not show any patient survival difference in HPV-positive cases (Appendix B; Table A1). In contrast, in HPV-negative cases, only when p75NTR high staining was accompanied by high NTRK1 staining compared with the other cases where both p75NTR and NTRK1 were low or not present, or only one of them was present, the patient survival was significantly lower $(p=0.013)$ in the Log Rank (Mantel-Cox) pairwise comparison $(n=64)$ (Appendix B; Table A1). Taken together, in HPV-positive cases an increased NTRK1 might be related with lower patient survival option, but this trend was not significant yet in the available patient collective. In HPV-negative cases the high expression of NTRK1 and the presence of p75NTR at the same time showed a statistically significant lower survival.

\subsection{NGF Receptors in SCC-25, Detroit 562 and UPCI-SCC090 Cells}

We described before that NGF gene expression is confined to normal and malignant epithelial cells and both normal and malignant epithelial cells might express NGF receptors. In HNSCC the expression pattern was not different in HPV-positive and -negative tissue samples, both NGF receptors could have been present in tumor cell nests. In a further step, we used SCC-25, Detroit 562 and UPCI-SCC090 HNSCC cell lines for investigation of NGF receptors; the NGF gene expression has been confirmed before (Figure 1A). SCC-25 cells were originally isolated from the primary tumor of a patient with tongue carcinoma $[13,29]$. SCC-25 cells are from primary oral SCC, maintained in in vitro cultures, might be also xenografted, but they grow only in severe combined immunodeficiency (SCID) mice and not in athymic mice. SCC-25 cells did not show metastatic potential in mouse xenograft models [30]. In vitro, SCC-25 cells were published to be radioresistant [31]. SCC-25 cells contain a deletion and a frame shift in codon 209 of the protein coding region of the TP53 gene and synthesize a truncated p53 protein, which probably quickly degrades (own Sanger sequencing results, and Western blot with mouse monoclonal DO-7 p53 N-terminal specific antibody; Appendix C, Figure A2). Detroit 562 cells demonstrated radio and chemoresistance [32,33], and it is a potential metastatic cell line in xenograft models [34]. Detroit 562 cells were originally isolated from the malignant pleural effusion of an OSCC $[35,36]$. A frequent gain of function mutation R175H of TP53 gene is contained in Detroit 562 cells [37], which has been confirmed by us utilizing Sanger sequencing. Both SCC-25 and Detroit 562 cells were HPV-negative [37]. The UPCI-SCC090 cell line has been established by Robert Ferris and co-workers [38]. UPCI-SCC090 cells contain genome integrated HPV-16 DNA. The UPCI-SCC090 cells synthesize both p16 ${ }^{\mathrm{INK} 4}$ surrogate HPV marker protein and E6, E7 HPV oncogene product proteins [38]. Ferris et al. [38] published a wild-type tumor suppressor TP53 gene in this cell line. In our hands, the protein coding region of UPCI-SCC090 TP53 gene contained the following miss-match nucleotide alterations in the following codons: D49V, P72R, T150A, and R209G. None of these have been reported to have any consequences in the $\mathrm{p} 53$ protein function, and they might be polymorphisms similar to P72R. We have done IHC analysis in agarose and paraffin embedded UPCI-SCC090 cells using diagnostic antibodies against $\mathrm{p} 53$ protein and $\mathrm{p} 16^{\mathrm{INK} 4}$. p53 protein showed a typical scattered distribution (Figure 5A), which is usually observed in patients with no p53 mutations [39], and p16 ${ }^{\text {INK4 }}$ was homogeneously distributed in all cells (Figure 5B).

The IHC staining of low and high affinity NGF receptors was also investigated in formalin fixed and paraffin embedded pellets of the above-introduced cell lines. SCC-25 cells were heterogeneous containing the majority of the cells without any NGF receptors, but also scattered cells expressing either low NTRK1 or well visible p75NTR. Both receptors were not present together (Figure 6A, in the figure insets the separate expression of NGF receptors is well visible). All Detroit 562 cells were p75NTR positive and they did not contain any NTRK1 (Figure 6B). The UPCI-SCC090 cells culture contained cells without any NGF receptors, and also frequently cells with high expression of NTRK1 were present, while low p75NTR positive cells were very rare (Figure 6C). 

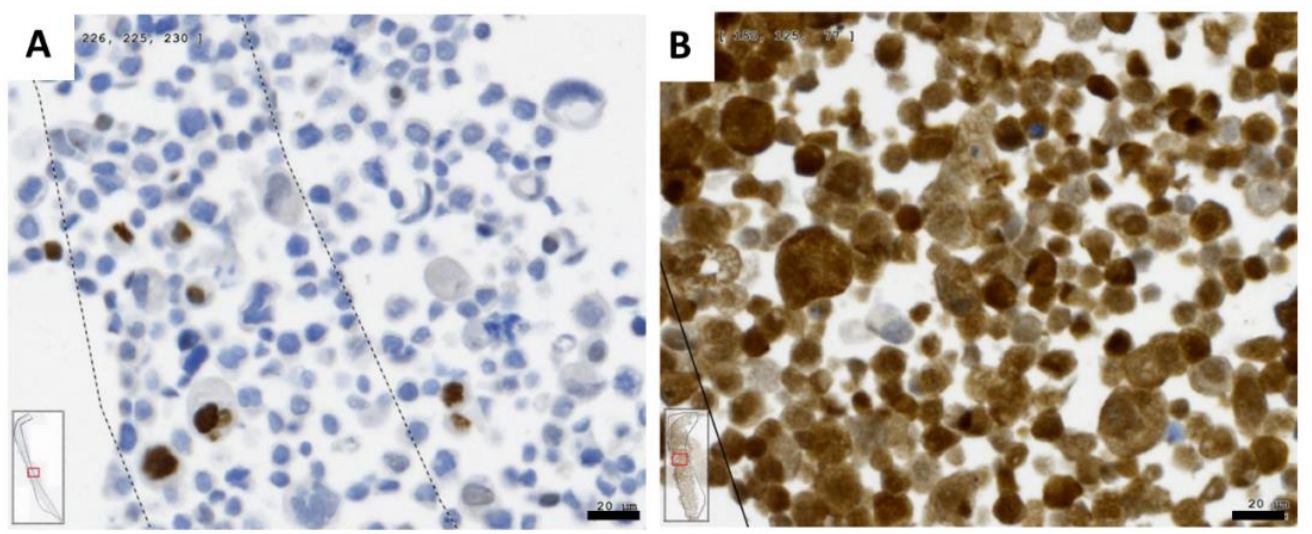

Figure 5. p53 (A); and p16 ${ }^{\mathrm{INK} 4}(\mathbf{B})$ representation in UPCI-SCC090 cells. Cells $\left(2-4 \times 10^{6}\right)$ were collected by centrifugation and embedded as cell pellet in agarose followed by embedding in paraffin (Supplementary Information, Supplementary Methods). Five micrometer thick sections have been cut from the cell pellets, stained using p53 and p16 ${ }^{\mathrm{INK} 4}$ specific antibodies, and photographed using the TissueFaxs system. Bars: $20 \mu \mathrm{m}$.
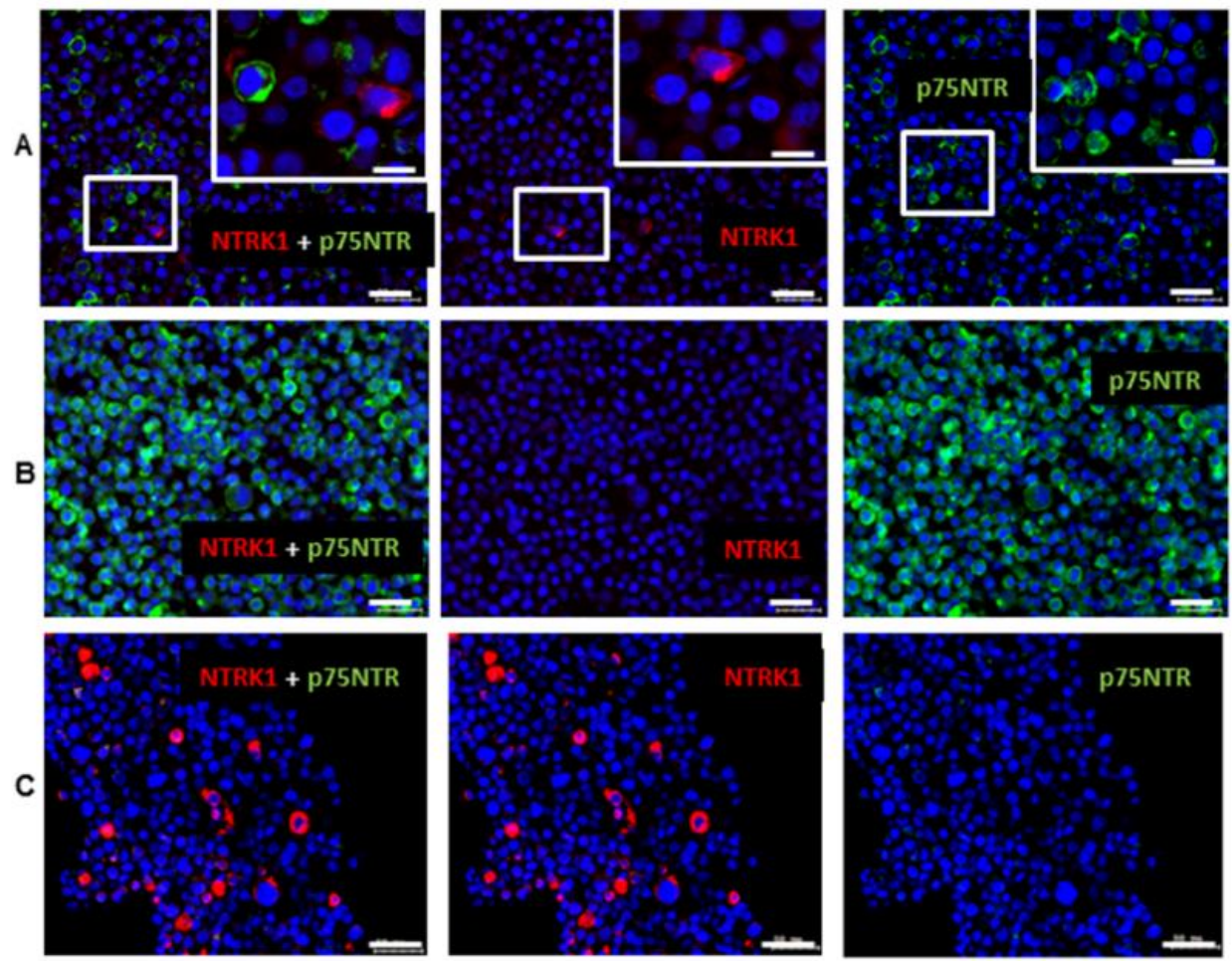

Figure 6. NTRK1 (red) and p75NTR (green) representation in: SCC-25 cells (A); Detroit 562 cells (B); and UPCI-SCC090 cells $(\mathrm{C})$. Cells $\left(2-4 \times 10^{6}\right)$ were collected by centrifugation and embedded as cell pellet in agarose followed by embedding in paraffin (Supplementary Information, Supplementary Methods). Five micrometer thick sections have been cut from the cell pellets, stained using NTRK1 and p75NTR specific antibodies, and photographed using the TissueFaxs system. The NGF receptors are shown together and separated. Scale bars: $50 \mu \mathrm{m}$ in the images and $10 \mu \mathrm{m}$ in the insets, blue: cell nuclei counterstained with DAPI. 


\subsection{Cell Survival Effects of NGF Treatments in SCC-25, Detroit 562 and UPCI-SCC090 Cells after Cell Cycle Arrest}

The next task was to test the hypothesis that NGF and any of its receptors might contribute to cell survival after cell cycle arrest. Cell cycle arrest after DNA damage is a common challenge for tumor cells in several therapeutic settings. Mitomycin C (MMC) is widely used in DNA-crosslinking/damage and cell cycle arrest studies [40], it preferentially eliminates proliferating cells, while showing less interference with the viability of G1-arrested cell populations [41] and it also does not affect cell migration [42]. A $30 \mathrm{~min} 10 \mu \mathrm{g} / \mathrm{mL}$ MMC-treatment in SCC-25 HNSCC cells enabled an up to $96 \mathrm{~h}$ cell cycle arrest, and there was no cell division within this time in this cell line [43]. In addition to cell cycle arrest, the MMC response was reported to induce cell death as both apoptosis and necrosis [44].

The used HNSCC cell lines were plated at $6.7 \times 10^{4}$ cells $/ \mathrm{mL}$ in serum-free culture media, the whole protein content of serum was replaced by serum albumin [32,43]. The cells were allowed to grow for $72 \mathrm{~h}$, and then were treated with $10 \mu \mathrm{g} / \mathrm{mL}$ MMC for $30 \mathrm{~min}$ followed by treatments for two times $48 \mathrm{~h}$ with $100 \mathrm{ng} / \mathrm{mL}$ NGF [45], or $100 \mathrm{ng} / \mathrm{mL}$ anti-NGF neutralizing antibody [46]. At the end of the whole experiment the SCC-25 culture contained $126.86 \pm 14.92 \%$ of the originally plated cells, the Detroit 562 culture contained $848.26 \pm 344.43 \%$ and the UPCI-SCC090 culture contained $207.71 \pm 82.48 \%$ (Figure 7A). The SCC- 25 cell culture was not only cell cycle arrested by a single short MMC treatment, but also contained $20.56 \pm 7.92 \%$ of cells stained positive with trypan blue, indicating incapacitated cell membrane functions, characteristic for necrosis or late apoptosis. The fraction of dead cells did not differ significantly after treatments with NGF or anti-NGF ( $p=0.74-0.99$ by Kruskal-Wallis test). The average number from three biological repeats of control cells ( $96 \mathrm{~h}$ after single $10 \mu \mathrm{g} / \mathrm{mL}$ 30 min MMC treatment) was defined as $100 \%$, and the cell numbers from NGF and anti-NGF treated cells (from three biological repeats) were compared to the control by Kruskal-Wallis test. There was no significant difference between the control and the treated cells in case of SCC-25 using any of the treatments ( $p>0.99$, Figure 7B). The Detroit 562 cell culture was still expanding after $96 \mathrm{~h}$ of the single short MMC treatment, and contained $8.07 \pm 3.63 \%$ of cells stained positive with trypan blue, which was comparable with routine cell culture conditions. The fraction of dead cells did not differ significantly after treatments with NGF or anti-NGF ( $p=0.1-0.74$ by Kruskal-Wallis test). The average number from three biological repeats of control cells ( $96 \mathrm{~h}$ after single $10 \mu \mathrm{g} / \mathrm{mL} 30 \mathrm{~min}$ MMC treatment) was defined as $100 \%$, and the cell numbers from NGF and anti-NGF treated experiments (from three biological repeats) were compared to the control by Kruskal-Wallis test. There was no significant difference between the control and the treated cells by Detroit 562 cells using any of the treatments $(p>0.99$, Figure 7C). The UPCI-SCC090 cell culture doubled after the single short MMC treatment, compared to the plated cell numbers (Figure 7A), and contained $6.09 \pm 7.04 \%$ of cells stained positive with trypan blue, which was comparable with routine cell culture conditions. The fraction of dead cells did not differ significantly after treatments with NGF, or anti-NGF ( $p=0.16-0.48$ by Kruskal-Wallis test). The average number from three biological repeats of control cells (96 h after single $10 \mu \mathrm{g} / \mathrm{mL} 30 \mathrm{~min} \mathrm{MMC}$ treatment) was defined as 100\%, and the cell numbers from NGF and anti-NGF treated experiments (from three biological repeats) were compared to the control by Kruskal-Wallis test. NGF $(100 \mathrm{ng} / \mathrm{mL})$ provided a significant increase ( $p=0.008$, Figure 7D) and $100 \mathrm{ng} / \mathrm{mL}$ anti-NGF neutralizing antibody assured a significant decrease ( $p=0.018$, Figure 7D) of the cell numbers. These results are summarized in Table 1. 
A

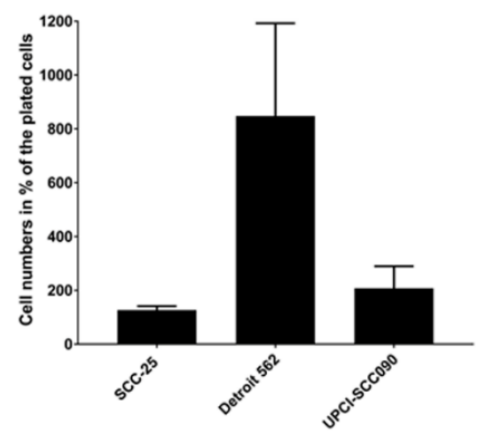

C

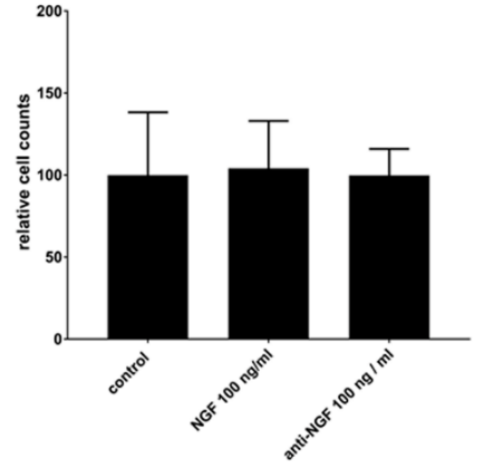

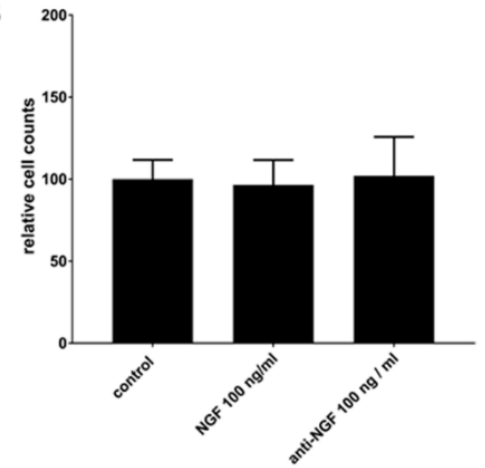

D

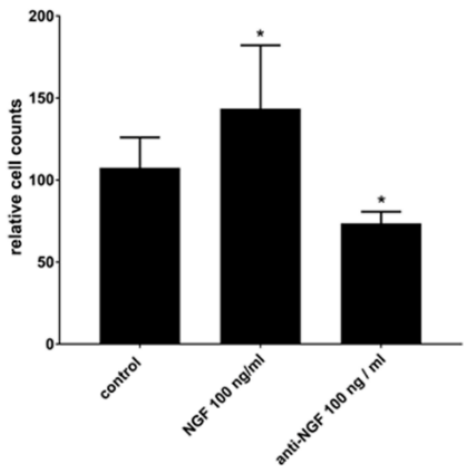

Figure 7. (A) Effects of MMC $96 \mathrm{~h}$ after a single $10 \mu \mathrm{g} / \mathrm{mL}$ treatment for $30 \mathrm{~min}$ in SCC-25, Detroit 562 and UPCI-SCC090 cells, the plated $6.7 \times 10^{4}$ cells were considered as $100 \%$. SCC- 25 cell culture remained at the plated level, Detroit 562 cell culture expanded and UPCI-SCC090 cell culture doubled after 96 h. Relative cell counts in SCC-25 (B), Detroit 562 (C) and UPCI-SCC090 (D) cells after two times $48 \mathrm{~h}$ of NGF and neutralizing anti-NGF antibody treatments after a single MMC-induced cell cycle arrest. Control (MMC-treated but not NGF or anti-NGF treated) cell counts were taken as $100 \%$ by all cell lines. Cell counts were analyzed by Graphpad Prism 7.01, were normal distributed and the mean values and SD of NGF and anti-NGF treated cells were compared with the control using one-way analysis of variance (ANOVA) and Dunnett's multiple comparisons test. * $p<0.05$.

Table 1. Effects of NGF and anti-NGF neutralizing antibody treatments on the cell numbers in SCC-25, Detroit 562 and UPCI-SCC090 cells after cell cycle arrest and treatments. Cell counts displayed as cells $1 \times 10^{4} / \mathrm{mL}$. From all cell lines $6.7 \times 10^{4}$ cells $/ \mathrm{mL}$ were plated in serum-free culture media.

\begin{tabular}{cccccccc}
\hline \multirow{2}{*}{ Cell Lines } & \multicolumn{2}{c}{ Untreated } & \multicolumn{2}{c}{ NGF 100 ng/mL } & \multicolumn{2}{c}{ Anti-NGF 100 ng/mL } \\
\cline { 2 - 6 } & $\begin{array}{c}\text { Trypan-Blue } \\
\text { Negative }\end{array}$ & $\begin{array}{c}\text { Trypan-Blue } \\
\text { Positive }\end{array}$ & $\begin{array}{c}\text { Trypan-Blue } \\
\text { Negative }\end{array}$ & $\begin{array}{c}\text { Trypan-Blue } \\
\text { Positive }\end{array}$ & $\begin{array}{c}\text { Trypan-Blue } \\
\text { Negative }\end{array}$ & $\begin{array}{c}\text { Trypan-Blue } \\
\text { Positive }\end{array}$ & $\begin{array}{c}\text { Repeats } \\
\text { SCC-25 }\end{array}$ \\
\hline P.5 \pm 1 & $1.7 \pm 0.7$ & $8.2 \pm 0.6$ & $1.1 \pm 0.1$ & $8.7 \pm 0.8$ & $1.2 \pm 0.5$ & 6 \\
Detroit 562 & $56.8 \pm 23.1$ & $4.6 \pm 2.1$ & $59.0 \pm 6.7$ & $2.0 \pm 1.1$ & $56.7 \pm 3.75$ & $2.4 \pm 1.4$ & 6 \\
UPCI-SCC090 & $13.9 \pm 5.5$ & $0.8 \pm 1.0$ & $19.9 \pm 1.5$ & $0.6 \pm 0.2$ & $10.2 \pm 0.3$ & $0.1 \pm 0.1$ & 6 \\
\hline
\end{tabular}

\section{Discussion}

Based on available references $[47,48]$ NGF was hypothesized as a potential trophic factor available from epithelial sources in HNSCC tissue. In HNSCC tumor specimens and in UPPP controls, NGF mRNA was detected by RT-PCR and ISH in epithelial cells including basal cells of normal squamous cell epithelium and malignant tumor cells in cancer cell nests. Over $80 \%$ of HNSCC specimens showed positive reaction for high affinity NGF receptor, NTRK1, and nearly all of them a high positive reaction in cancer cell nests. In contrast to NTRK1, the low affinity receptor p75NTR was present in $51.61 \%$ of HNSCC samples. p75NTR protein synthesis was not more frequent in cancer cell nests than in normal mucosa, but NTRK1 staining was significantly higher in the cancer cell nests of HNSCC than in the normal epithelium. Interestingly, high significant $(p=0.005)$ negative correlation 
was found between p75NTR and NTRK1 staining intensity (correlation coefficient: -0.7$)$. Even if both NTRK1 and p75NTR were present in the tumor cell nests, they were mutually exclusive, meaning that $\mathrm{NTRK}^{+}$and $\mathrm{p} 75 \mathrm{NTR}^{+}$cells are two separate cell populations of the HNSCC tumor cell nests; moreover, this finding could be extended to cultured cell lines, as revealed on Figure 6.

Similar to previous findings in prostate cancer [49-51], cancer cell nests containing both NGF and NTRK1 suggested an important autocrine tumor maintenance function of this system in HNSCC. We refer to a previously published issue that the NTRK1-NGF axis can be a survival system, which rescues cells from cell death [17].

In HNSCC, the HPV-carcinogenesis has been published to contribute to preferred patient survival $[25,26]$ compared to HPV-negative background, which has been confirmed by our data as well. The HPV carcinogenesis background did not show any relation with NGF gene expression or with IHC detection of NGF receptors. Patient survival data were related to NTRK1 and p75NTR staining levels, and none of the NTRK1 and p75NTR staining levels did show any significant survival effects in Kaplan-Meier censored case survival processing. Additionally, HPV-positive and -negative cases were also separately processed. p75NTR presence or absence did not show any survival difference in HPV-positive cases, as well as the NTRK1 levels were also not related with a significant survival influence. A significant effect has been seen in HPV-negative cases, when p75NTR high staining was accompanied by high NTRK1 staining in the tumor cell nests, which was related with significantly lower patient survival compared with cases where both p75NTR and NTRK1 were low or not present, or only one of them was present. These data suggest that the positive HPV detection is related with patient survival benefit, as confirmed by the current data and by published references $[25,26]$, and it is at the moment the strongest considerable patient survival influencing factor in $\mathrm{HNSCC}$. In $\mathrm{HPV}^{+}$cases the neurotrophin receptors were not related with significant survival effects. These data indicate that the effects of neurotrophin receptors levels might be secondary to the strong beneficial effects related with still unclear biological mechanisms associated with high p16 ${ }^{\mathrm{INK} 4} \mathrm{IHC}$.

The current statistical data of a limited patient collective were compared with experimental results on three HNSCC cell lines. All three cell lines produced sufficient amounts of NGF. The neurotrophin receptors expression was scattered in SCC- 25 cells, and the majority of the cells were without any NGF receptors. In contrast, all Detroit 562 cells were p75NTR positive, but they did not contain any NTRK1. The UPCI-SCC090 cells culture frequently contained cells with high expression of NTRK1, while p75NTR positive cells were very rare. In these three cell lines a single $30 \mathrm{~min} 10 \mu \mathrm{g} / \mathrm{mL}$ MMC-treatment in serum and growth-factor-free conditions, which enabled an up to $96 \mathrm{~h}$ cell cycle arrest in SCC- 25 cells, was used as an anti-proliferative challenge. The MMC-challenge was followed by two-times $48 \mathrm{~h}$ NGF or neutralizing NGF antibody treatment. Both the NTRK1-positive UPCI-SCC090 culture (at 2-fold) and the p75NTR-positive Detroit 562 culture (at 8-fold) increased after the MMC-challenge without NGF treatment (based only on the self-production of NGF), and the SCC-25 culture remained arrested. Interestingly, SCC- 25 and Detroit 562 cells did not react on given $100 \mathrm{ng} / \mathrm{mL}$ NGF or $100 \mathrm{ng} / \mathrm{mL}$ neutralizing anti-NGF antibody, while UPCI-SCC090 cells did.

The received results allow the following conclusions. NGF might improve cell survival after a cell cycle arrest in tumor cell nests (or cell culture), which contain sufficiently high number of cells with NTRK1. High expression of p75NTR most optimally in all cells of the culture (as by Detroit 562) does not lead to cell survival increase after NGF treatment or to cell survival reduction after NGF neutralization. Nevertheless, p75NTR is still involved in cell survival support in Detroit 562 cells, without any relation to NGF. This, most probably NGF-independent mechanism was the one, which allowed an eight-fold cell culture expansion after a single MMC challenge. This effect of p75NTR might probably work through p21(WAF1), which it also contributes to drug resistance, as published by Verbeke et al. [23].

The clinical and experimental data of this study, taking also published references into consideration, delivers the following outcomes: 
$-$

The NGF expression and neurotrophin receptor synthesis do not explain the patient survival benefit of $\mathrm{HPV}^{+} \mathrm{HNSCC}$ patients, and do not contribute to the mechanistic understanding of the phenomenon of the good prognosis of HPV-positivity in HNSCC. The NGF-neurotrophin receptor axis might be a negative risk contributor to patent survival, probably weaker than the positive effects of HPV-positivity.

As reviewed by Tomellini et al., p75NTR can cooperate with other receptors and modify signaling pathways, by which it is able to interact both in synergistic and antagonistic ways. p75NTR, does not have an independent intrinsic enzymatic activity, it acts more as modifier of other signaling pathways [21], and as reported, it might be responsible for drug resistance [23]. At the same time, the NGF and NTRK1 receptor form a previously unknown important autocrine epithelial survival axis in HNSCC, which might be active in cell survival mechanisms following chemotherapeutic treatments of DNA crosslinking agents as cisplatin or MMC. The suggestion of NGF and NTRK1 autocrine loop in HNSCC is absolutely novel. Nevertheless, similar findings from other oncological fields support the relevance of this issue, as for example in breast cancer the formation of NGF and NTRK1 autocrine axis was evidenced as well [52]. In prostate cancer [53], the development of NGF/NTRK1 or BDNF/NTRK2 autocrine signaling pathways is an escape mechanism, from both the androgen control and the paracrine dependence of stromal cells produced neurotrophins. The strength of our study is that we clearly evidence the NGF and NTRK1 co-localization with combined IHC and ISH methods. Similar to HNSCC tissue samples, the p75NTR and NTRK1 receptors were in different cells even in cultured cell lines, also if both receptors were expressed.

\section{Materials and Methods}

\subsection{Patient Samples, Immunohistochemistry}

The procedures followed were in accordance with the ethical standards of the committee on human experimentation of the institution and in accord with the Helsinki Declaration of 1975 as revised in 1983. Permission was obtained from the local ethics committee to collect pretreatment biopsy samples for molecular biological investigation, paraffin embedding, sectioning and immunohistochemical analysis (Reference Number: UN4428 303/4.14). Informed consent was obtained from all patients. Neurotrophin receptor determinations were performed in 93 randomly selected specimens of incident locally advanced HNSCC treated between March 2010 and October 2017 at the Department of Otorhinolaryngology-Head \& Neck Surgery, Medical University of Innsbruck. Clinical data are summarized in Appendix B, Table A2. As a control, 12 normal mucosa tissue samples derived from uvulopalatopharyngoplasties (UPPP) in patients with sleep apnea syndrome were included. Pretreatment tumor samples were obtained during 
diagnostic panendoscopy. Patient samples were paraffin embedded, sectioned and immunostained as described in Supplementary Information, Supplementary Methods, antibody information is provided in Supplementary Information, Supplementary Methods Table S1.

\subsection{In Situ Hybridization}

In situ hybridization was performed on $5 \mu \mathrm{m}$ paraffin sections in a Ventana Discovery Classic immunostainer (Tucson, AZ, USA) using Ribomap kit and Bluemap kit (Ventana) utilizing digoxigenin (DIG) labeled riboprobes described in Supplementary Information, Supplementary Methods. For antigen retrieval CC1 buffer (mild) and Protease 3 (16 min) were used. DIG-labeled riboprobe $(200 \mathrm{ng} / \mathrm{mL})$ and unlabeled sheared salmon sperm DNA $(160 \mu \mathrm{g} / \mathrm{mL})$ (Ambion, Fisher Scientific, Vienna, Austria) were added in Ribohybe (Ventana) $(100 \mu \mathrm{L})$ on each slide. The salmon sperm DNA was used to compete the cell nuclear DNA binding of the DIG-labeled riboprobe. The probe hybridization was performed at $66^{\circ} \mathrm{C}$ for three hours followed by stringency $2 \times S C C$ washes, $3 \times 8$ min at $70{ }^{\circ} \mathrm{C}$, as suggested by DIG "In situ Application Note No. 1" (Roche Diagnostics, Mannheim, Germany, 2012) [54]. The hybridization signal was detected by anti-DIG Fab fragments (alkaline phosphatase or rhodamin coupled) purchased from Roche Life Sciences, and by the Bluemap kit (Roche, Ventana) as instructed by the providers. If the alkaline phosphatase was used, the BCIP, NBT substrate time was $3 \mathrm{~h}$. The cell nuclei were counterstained in red by Red Counterstain II (Ventana) or by DAPI in case of the fluorescence system. If using fluorescence, the in situ hybridization was directly followed by the incubation with primary and secondary antibodies as described in the immunohistochemistry section in Supplementary Information, Supplementary Methods. The antisense riboprobe showed a specific reaction, while the control probe did not react specifically.

\subsection{Image Analysis of Immunohistochemistry and In Situ Hybridization}

The immunostained and riboprobes reacted sections were digitalized at $20 \times$ magnification utilizing a TissueFaxs Plus System coupled onto a Zeiss ${ }^{\circledR}$ Axio Imager Z2 Microscope (Jena, Germany). Regions of interest were then acquired using the TissueFaxs (TissueGnostics ${ }^{\circledR}$, Vienna, Austria). The intensity of signals localized onto the affixed sections was then evaluated using HistoQuest ${ }^{\circledR}$ (TissueGnostics) software. Details of the intensity quantification are given in Supplementary Information, Supplementary Methods.

Alternatively, p75NTR and NTRK1 immunostaning were scored (0): no staining; low (1): under $30 \%$ of cells positive; middle (2): $30-66 \%$ of cells positive; and high (3): more than $66 \%$ of cells positive in cancer cell nests) and Mann-Whitney test was used to detect differences between HNSCC and UPPP. p75NTR staining was also evaluated as staining present (1) or absent (0).

\subsection{Cell Lines}

SCC-25 and UPCI-SCC090 cells were acquired from the German Collection of Microorganisms and Cell Cultures (DSMZ, Braunschweig, Germany, DSMZ no.: ACC 617). SCC-25 cells were cultured in DMEM/F12 medium. UPCI-SCC090 [38] cells were cultured in EMEM medium supplemented with 10\% FBS, $2 \mathrm{mM}$ L-glutamine, 100 units/mL penicillin and $100 \mu \mathrm{g} / \mathrm{mL}$ streptomycin [14,15,32]. Detroit 562 cells were purchased from Cell Lines Service (CLS, Eppelheim, Germany) and were cultured in EMEM medium supplemented with 10\% FBS, 2 mM L-glutamine, 100 units $/ \mathrm{mL}$ penicillin and $100 \mu \mathrm{g} / \mathrm{mL}$ streptomycin. For experimental purposes, cells were cultured in an albumin-containing medium where serum proteins were replaced by $4.4 \mathrm{~g} / \mathrm{L}$ bovine serum Page: 13 Detected space and/or hyphen in reference call-out. This is not recognized, space should be removed and hyphen changed to en dash. Albumin from PAA Laboratories (Pasching, Austria).

\subsection{Evaluation of the NGF Receptors in Cultured Cell Lines}

Routinely cultured cell lines $\left(2-4 \times 10^{6}\right)$ were collected by centrifugation and embedded as cell pellet in agarose as published before [55], modified as follows: Cells were harvested by centrifugation at 
$290 \times g$ for $10 \mathrm{~min}$ at $4{ }^{\circ} \mathrm{C}$, and the resulting pellet was fixed in $10 \mathrm{~mL}$ neutral buffered $4 \%$ formaldehyde solution (Flintsbach am Inn, Germany). After fixation, the cells were centrifuged by $400 \times g$ for $10 \mathrm{~min}$ at room temperature. The cell pellet was resuspended in $300 \mu \mathrm{L}$ PBS, transferred to Eppendorf tube $(1.5 \mathrm{~mL})$, and kept on ice. Low melting point agarose (with gelling temperature point $34-37^{\circ} \mathrm{C}$ ) was prepared in PBS as 3\% solution in labor glassware by microwave warming and it was equilibrated in a thermoblock to $65^{\circ} \mathrm{C}$ for at least $30 \mathrm{~min}$. The $300 \mu \mathrm{L}$ PBS — cell suspension was also equilibrated to $65{ }^{\circ} \mathrm{C}$ for not more than $10 \mathrm{~min}$. Six hundred microliters melted equilibrated agarose was pipetted to the cell suspension, followed by spinning at $2000 \times \mathrm{g}$ for $5 \mathrm{~min}$ at room temperature. After that, the tube was placed on ice, the cell pellet was trimmed and it was placed in embedding cassette. The cell pellet in the cassette was stored in PBS containing $0.05-0.1 \%$ sodium azide until embedded in paraffin (Supplementary Information, Supplementary Methods).

Similar to the tissue sections, from the cell pellets, $5 \mu \mathrm{m}$ thick sections have also been cut. The cell sections did not contain any overlaps, the cells were distributed. The cell sections were stained immunohistochemically exactly ident with the tissue sections. The $\%$ of NTRK1 and p75NTR positive cells was identified after scanning the sections in the TissueFaxs system and evaluating with Histoquest software (Supplementary Information, Supplementary Methods).

\subsection{Cell Treatments}

For the treatment with $100 \mathrm{ng} / \mathrm{mL}$ NGF or $100 \mathrm{ng} / \mathrm{mL}$ anti-NGF neutralizing antibody (RnD Systems, Minneapolis, MN, USA), $1.5 \mathrm{~mL} /$ well cell suspension of $6.7 \times 10^{4}$ cells $/ \mathrm{mL}$ were plated in 12-well plates (Falcon ${ }^{\mathrm{TM}}$, Durham, NC, USA) in serum-free, albumin containing medium [43] and cultured for $72 \mathrm{~h}$. After that, the cells were washed with PBS and incubated with $10 \mu \mathrm{g} / \mathrm{mL}$ Mitomycin $\mathrm{C}$ (Sigma-Aldrich ${ }^{\circledR}$, St. Louis, MO, USA) in serum-free albumin-containing medium for 30 min at $37^{\circ} \mathrm{C}$ ensuring cell cycle arrest [42]. Then the cells were washed twice with albumin-containing medium and subsequently treated with albumin-containing medium for two times $48 \mathrm{~h}$ supplied with $100 \mathrm{ng} / \mathrm{mL}$ recombinant human NGF [45] or with $100 \mathrm{ng} / \mathrm{mL}$ anti NGF neutralizing antibody (RnD Systems) for altogether $96 \mathrm{~h}$. After completion of treatments, the cells were used for cell counting with trypan blue staining (Sigma, Darmstadt, Germany) in a Neubauer chamber (Paul Marienfeld GmbH \& Co. KG, Lauda-Königshofen, Germany).

\subsection{RNA Isolation and PCR}

For RNA isolation, 2-4 $\times 10^{6}$ cells or 2-3 mm tissue slices were collected and lysed in $1 \mathrm{~mL}$ TRIzol ${ }^{\circledR}$ Reagent $\left(\right.$ Ambion $^{\circledR}$, Life technologies ${ }^{\mathrm{TM}}$, Carlsbad, CA, USA), and RNA was isolated as instructed by the manufacturer of TRIzol. RNA concentrations were determined by photometric measurements (BioPhotometer plus 6132, Eppendorf, Germany). Total RNA was reverse transcribed by M-MuLV Reverse Transcriptase (GeneON, Ludwigshafen am Rhein, Germany) in a MyiQ ${ }^{\mathrm{TM}}$ cycler (BIO-RAD Laboratories, Inc., Hercules, CA, USA) following the manufacturer's instructions. PCR of cDNA transcripts was performed in a $\mathrm{MyiQ}^{\mathrm{TM}}$ cycler (BIO-RAD Laboratories, Inc., USA) using Go-Taq master mix (Promega, Madison, WI, USA) and the following forward: $5^{\prime}$-CAC ACT GAG GTG CAT AGC GT-3' and reverse: $5^{\prime}$-TGA TGA CCG CTT GCT CCT GT-3' primers for NGF, and forward: ACCCTGAAGTACCCCATCGA; reverse: TGTCACCTTCACCGTTCCAG for the housekeeping gene ACTB. The primers were synthesized by Invitrogen ${ }^{\mathrm{TM}}$ (Darmstadt, Germany). The PCR setup and the cycling conditions were instructed in the manual of Go-Taq. PCR products were electrophoresed in $1 \%$ agarose run in Tris-Acetate-EDTA buffer for one hour at 100 volts. Gels were photographed in an Azure C500 (Azure Biosystems, Dublin, CA, USA).

\section{Conclusions}

NGF is produced in sufficient amounts in normal oral epithelium and in tumor cells of HNSCC, including cultured cell lines. The basal cells of normal oral mucosa synthesize both NTRK1 high affinity and p75NTR low affinity receptors. The synthesis of these two receptors is separated to two cell 
populations in the HNSCC tumor cell nests: high levels of NTRK1 and p75NTR were not present in the same cells of HNSCC tumor tissue and cultured cell lines. NGF was able to transduce a survival signal via NTRK1, if sufficient number of high NTRK1+ cells were present in the culture, but not via p75NTR, which also confirmed that p75NTR owes its signaling ability to its association with other cytoplasmic partners [21]. It seems that, in the heterogenic HNSCC tumor cell nests and cultured cell lines, several survival strategies are present at the same time: one of them is the autocrine NGF-NTRK1 system, and a possible other is the NGF-independent (since p75NTR ${ }^{+}$cells have low or no NTRK1) system, which offer a therapy resistance over p21/WAF1. More possible mechanisms at the same time ensure multiple therapy resistance options for HNSCC tumor cell nests.

Supplementary Materials: The following are available online at http:/ /www.mdpi.com/1422-0067/19/6/1771/ s1.

Author Contributions: J.D., H.R. and A.S.-F. conceived and designed the experiments; V.H.S. and D.D. collected patient cohort and analyzed clinical data; S.R. prepared paraffin sections, and performed histological and pathological analysis; A.R. and R.T. performed the cell treatments and cell-based experiments; W.D. performed the TissueFaxs and Histoquest quantification; L.J.C. participated in the in situ hybridization and in the establishment and utilization of fluorescence methods; R.G., conceived and established the IHC methods and the cell pellet experimental concept; J.D., D.D. and H.R. statistically analyzed the data; A.R. contributed reagents/materials/analysis tools; J.D. wrote the paper; and all authors revised and improved the manuscript to its final form. Authorship was limited to those who have contributed substantially to the work reported.

Funding: This research was funded by Austrian Science Funds (FWF) Project Number: P25869-B13 and partly by the "Österreichische Nationalbank Anniversary Fund, Project Number 15607".

Conflicts of Interest: The authors declare no conflict of interest.

\section{Abbreviations}

$\begin{array}{ll}\text { ACTB } & \text { Beta-actin gene } \\ \text { BCIP } & \text { bromo-chlor-indol-phosphate } \\ \text { BDNF } & \text { brain-derived neurotrophic factor } \\ \text { DAPI } & 4^{\prime} \text {,6-Diamidin-2-phenylindol } \\ \text { DIG } & \text { digoxigenin } \\ \text { EDTA } & \text { Ethylene diamine tetra acetate } \\ \text { EMT } & \text { epithelial-to-mesenchymal transition } \\ \text { HNSCC } & \text { head and neck squamous cell carcinoma } \\ \text { HPV } & \text { human papilloma virus } \\ \text { LCR } & \text { long control region } \\ \text { LNGFR } & \text { Low-affinity Nerve Growth Factor } \\ \text { MMC } & \text { mitomycin C } \\ \text { NBT } & \text { Nitro-blue-tetrazolium } \\ \text { NGF } & \text { nerve growth factor } \\ \text { NTRK } & \text { neurotrophic receptor tyrosine kinase } \\ \text { OSCC } & \text { oral squamous cell carcinoma } \\ \text { P75NTR } & \text { p75 neurotrophin receptor } \\ \text { PBS } & \text { Phosphate buffered saline } \\ \text { PCR } & \text { Polymerase chain reaction } \\ \text { SCID } & \text { severe combined immunodeficiency } \\ \text { Trk } & \text { tropomyosin-related kinase } \\ \text { UPPP } & \text { uvulopalatopharyngoplasty } \\ & \end{array}$




\section{Appendix A}

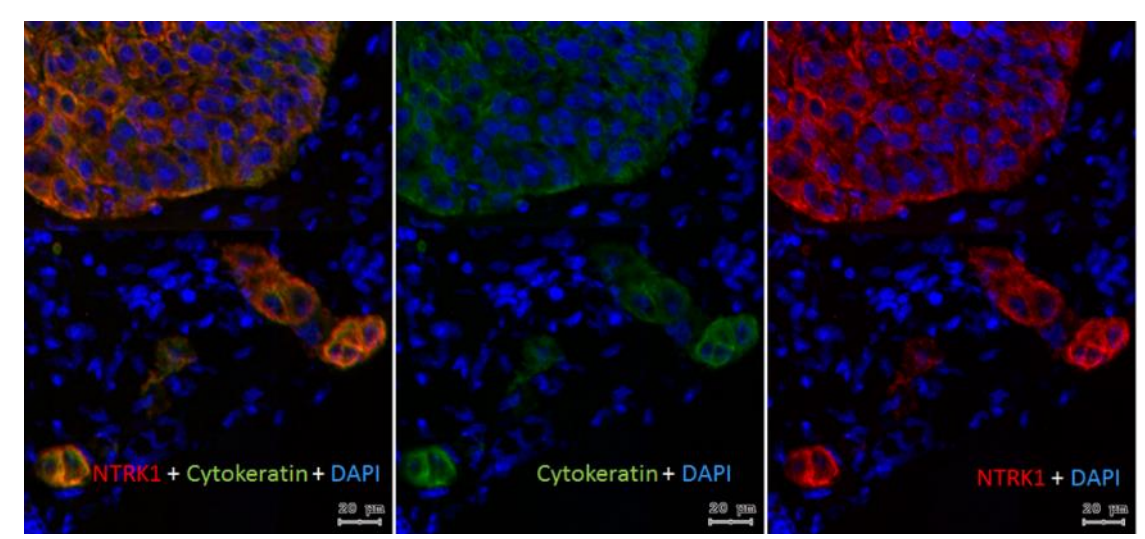

Figure A1. NTRK1 and Cytokeratin co-localisation; red: NTRK1, green: Cytokeratin, blue: cell nuclei counterstained, scale bars: $50 \mu \mathrm{m}$.

A double staining was performed using anti-NTRK1 rabbit monoclonal antibody (detected in red) and mouse monoclonal pan-cytokeratin (detected in green) in larynx SCC. The cytokeratin and NTRK1 staining reactions were comparable, suggesting that the NGF receptor (NTRK1) is synthesized in epithelial (cytokeratin-positive) tumor cells. The immunohistochemical reactions are shown together and separately.

\section{Appendix B}

Comparison of patient survival effects of NTRK1 and p75NTR immunohistochemical staining levels in HPV-negative and -positive HNSCC. Survival rate is the per cent of patients alive up to 96 months out of all patients. Survival time is the estimated mean \pm std. error. The survival processing has been censored. The majority of the cases were not observed for 96 months.

In HPV-negative cases, the presence of p75 showed lower survival than its absence, but the difference in the Log Rank (Mantel-Cox) pairwise comparison was not significant. In the HPV-positive cases, there was no significant difference in survival regarding NTRK1 or p75NTR staining or their combination. Interestingly, in HPV-negative cases $(n=64)$ where p75NTR high staining was accompanied by high NTRK1 staining compared with the other cases where both stainings were low or not present, or only one of them was present, the patient survival was significantly lower $(p=0.013)$ in the Log Rank (Mantel-Cox) pairwise. Although the number of cases in the group where p75NTR high staining was accompanied by high NTRK1 staining was low $(n=10)$, the other group contained 54 cases, the observation time between years 2010 and 2017 was short, as well as for many cases the individual observation time was also too short and the survival processing must have been censored, there was a clear significant effect. Nevertheless, a random influence can never be ruled out by low numbers of cases. Taken together, p75NTR, especially if combined with high NTRK1 staining, was related with poor survival in HPV-negative cases. 
Table A1. Comparison of patient survival effects of NTRK1 and p75NTR immunohistochemical staining levels in HPV-negative and -positive HNSCC.

\begin{tabular}{|c|c|c|c|c|c|c|c|}
\hline Analyzed Cases & $\begin{array}{l}\text { Investigated } \\
\text { Question }\end{array}$ & Compared Conditions & Cases & $\begin{array}{l}\text { Survival Rate, } \% * \text { in up } \\
\text { to } 96 \text { Months }\end{array}$ & $\begin{array}{l}\text { Survival Time, Months } \\
\text { (Mean } \pm \text { Std. Error) }\end{array}$ & Survival Effect & $\begin{array}{c}p \text {-Value by Log Rank } \\
\text { (Mantel-Cox) Pairwise over } \\
\text { Strata Comparison }\end{array}$ \\
\hline ALL & NTRK1 level & $\begin{array}{l}\text { NTRK1 level at control } \\
\text { NTRK1 level above control }\end{array}$ & $\begin{array}{l}18 \\
75\end{array}$ & $\begin{array}{l}66.6 \% \\
60.0 \%\end{array}$ & $\begin{array}{c}47.6 \pm 8.77 \\
52.86 \pm 5.93\end{array}$ & No significant effect & $p=0.703$ \\
\hline HPV-negative & NTRK1 level & $\begin{array}{l}\text { NTRK1 level at control } \\
\text { NTRK1 level above control }\end{array}$ & $\begin{array}{l}10 \\
54\end{array}$ & $\begin{array}{l}60.0 \% \\
57.4 \%\end{array}$ & $\begin{array}{l}43.6 \pm 11.26 \\
51.58 \pm 6.83\end{array}$ & No significant effect & $p=0.997$ \\
\hline HPV-positive & NTRK1 level & $\begin{array}{l}\text { NTRK1 level at control } \\
\text { NTRK1 level above control }\end{array}$ & $\begin{array}{c}7 \\
21\end{array}$ & $\begin{array}{l}85.7 \% \\
66.7 \%\end{array}$ & $\begin{array}{l}62.0 \pm 11.63 \\
41.03 \pm 5.68\end{array}$ & No significant effect & $p=0.388$ \\
\hline ALL & p75NTR reaction & $\begin{array}{l}\text { negative } \\
\text { positive }\end{array}$ & $\begin{array}{l}45 \\
48\end{array}$ & $\begin{array}{l}64.4 \% \\
58.3 \%\end{array}$ & $\begin{array}{l}47.87 \pm 5.14 \\
50.39 \pm 7.39\end{array}$ & No significant effect & $p=0.413$ \\
\hline HPV-negative & p75NTR reaction & $\begin{array}{l}\text { negative } \\
\text { positive }\end{array}$ & $\begin{array}{l}30 \\
34 \\
\end{array}$ & $\begin{array}{l}63.3 \% \\
52.9 \% \\
\end{array}$ & $\begin{array}{l}47.86 \pm 6.20 \\
45.75 \pm 8.50\end{array}$ & No significant effect & $p=0.279$ \\
\hline HPV-positive & p75NTR reaction & $\begin{array}{l}\text { negative } \\
\text { positive }\end{array}$ & $\begin{array}{l}14 \\
14\end{array}$ & $\begin{array}{l}71.4 \% \\
71.4 \%\end{array}$ & $\begin{array}{l}45.22 \pm 7.64 \\
50.6 \pm 9.30\end{array}$ & No significant effect & $p=0.995$ \\
\hline ALL & $\begin{array}{l}\text { combined high } \\
\text { NTRK1/p75NTR }\end{array}$ & $\begin{array}{c}\text { NTRK1/p75NTR are NOT } \\
\text { combined } \\
\text { Sign. NTRK1/p75NTR } \\
\text { combined }\end{array}$ & $\begin{array}{l}79 \\
14\end{array}$ & $\begin{array}{l}63.3 \% \\
50.0 \%\end{array}$ & $\begin{array}{l}56.84 \pm 5.77 \\
29.25 \pm 7.18\end{array}$ & No significant effect & $p=0.139$ \\
\hline HPV-negative & $\begin{array}{l}\text { combined high } \\
\text { NTRK1/p75NTR }\end{array}$ & $\begin{array}{c}\text { NTRK1/p75NTR are NOT } \\
\text { combined } \\
\text { Sign. NTRK1/p75NTR } \\
\text { combined }\end{array}$ & $\begin{array}{l}54 \\
10\end{array}$ & $\begin{array}{l}61.1 \% \\
40.0 \%\end{array}$ & $\begin{array}{l}56.41 \pm 6.74 \\
17.36 \pm 7.37\end{array}$ & $\begin{array}{l}\text { Significant worse } \\
\text { survival if both NTRK1 } \\
\text { and p75NTR are high }\end{array}$ & $p=0.013$ \\
\hline HPV-positive & $\begin{array}{l}\text { combined high } \\
\text { NTRK1/p75NTR }\end{array}$ & $\begin{array}{c}\text { NTRK1/p75NTR are NOT } \\
\text { combined } \\
\text { Sign. NTRK1/p75NTR } \\
\text { combined }\end{array}$ & $\begin{array}{l}24 \\
4\end{array}$ & $\begin{array}{l}70.8 \% \\
75.0 \%\end{array}$ & $\begin{array}{l}48.17 \pm 7.50 \\
44.50 \pm 6.72\end{array}$ & No significant effect & $p=0.552$ \\
\hline
\end{tabular}


Table A2. Patient Data.

\begin{tabular}{ccc}
\hline Tissue Type & Number of Cases & $\%$ \\
\hline HNSCC & 93 & 88.6 \\
UPPP epithelium & 12 & 11.4 \\
\hline Tumor_Localization & Number of Cases & $\%$ \\
\hline oral & 14 & 15.0 \\
nasopharynx & 4 & 4.3 \\
oropharynx & 39 & 41.9 \\
larynx & 21 & 22.6 \\
hypopharynx & 13 & 14.0 \\
other & 2 & 2.15 \\
Total & 93 & 100.0 \\
\hline Gender & Frequency & Percent \\
\hline Male & 85 & 90.9 \\
Female & 20 & 19.1 \\
Total & 105 & 100.0 \\
\hline HPV & Frequency & Percent \\
\hline Positive & 28 & 30.4 \\
Negative & 64 & 69.6 \\
Total & 92 & 100.0 \\
\hline
\end{tabular}

Mean age of patients: $60.17 \pm 13.32$ years; minimum: 28 ; maximum: 91.

\section{Appendix C}

Appendix C.1 TP53 mRNA Sequencing and Protein Results in SCC-25 Cells

TP53 mRNA amplification and sequencing in SCC-25 cells sequenced until 900 bases, which was ensured as reliable by the service provider. Explanations: Query: sequence from SCC-25 cells; Subject: database reference sequence: NM_001126112; Red label: changed sequence in SCC-25 cells; green label: original database sequence. $\mathrm{Y}$ is "C" or " $\mathrm{T}$ ".

Query 1 CATTTTCAGACCTATGGAAACTACTTCCTGAAAACAACGTTCTGTCCCCCTTGCCGTCCC 60

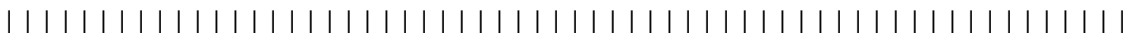

Sbjct 252 CATTTTCAGACCTATGGAAACTACTTCCTGAAAACAACGTTCTGTCCCCCTTGCCGTCCC 311

Query 61 AAGCAATGGATGATTTGATGCTGTCCCCGGACGATATTGAACAATGGTTCACTGAAGACC 120

||||||||||||||||||||||||||||||||||||||||||||||||||||||||||||||

Sbjct 312 AAGCAATGGATGATTTGATGCTGTCCCCGGACGATATTGAACAATGGTTCACTGAAGACC 371

Query 121CAGGTCCAGATGAAGCTCCCAGAATGCCAGAGGCTGCTCCCCGCGTGGCCCCTGCACCAG 180

| | | | | | | | | | | | | | | | | | | | | | | | | | | | | | | | | | | | | | | | | | | | | | | | | | | | |

Sbjct 372 CAGGTCCAGATGAAGCTCCCAGAATGCCAGAGGCTGCTCCCCCCGTGGCCCCTGCACCAG 431

Query 181CAGCTCCTACACCGGCGGCCCCTGCACCAGCCCCCTCCTGGCCCCTGTCATCTTCTGTCC 240 
Sbjct 432 CAGCTCCTACACCGGCGGCCCCTGCACCAGCCCCCTCCTGGCCCCTGTCATCTTCTGTCC 491

Query 241CTTCCCAGAAAACCTACCAGGGCAGCTACGGTTTCCGTCTGGGCTTCTTGCATTCTGGGA 300

111111111111111111111111111111111111111111111111111111111111111111111

Sbjct 492 CTTCCCAGAAAACCTACCAGGGCAGCTACGGTTTCCGTCTGGGCTTCTTGCATTCTGGGA 551

Query 301CAGCCAAGTCTGTGACTTGCACGTACTCCCCTGCCCTCAACAAGATGTTTTGCCAACTGG 360

1111111111111111111111111111111111111111111111111111111111111111111111

Sbjct 552 CAGCCAAGTCTGTGACTTGCACGTACTCCCCTGCCCTCAACAAGATGTTTTGCCAACTGG 611

Query 361CCAAGACCTGCCCTGTGCAGCTGTGGGTTGATTCCACACCCCCGCCCGGCACCCGCGTCC 420

111111111111111111111111111111111111111111111111111111111111111111111

Sbjct 612 CCAAGACCTGCCCTGTGCAGCTGTGGGTTGATTCCACACCCCCGCCCGGCACCCGCGTCC 671

Query 421 GCGCCATGGCCATCTACAAGCAGTCACAGCACATGACGGAGGTTGTGAGGCGCTGCCCCC 480

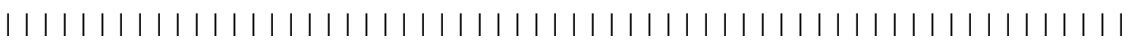

Sbjct 672 GCGCCATGGCCATCTACAAGCAGTCACAGCACATGACGGAGGTTGTGAGGCGCTGCCCCC 731

Query 481 ACCATGAGCGCTGCTCAGATAGCGATGGTCTGGCCCCTCCTCAGCATCTTATCCGAGTGG 540

||||||||||||||||||||||||||||||||||||||||||||||||||||||||||||||||

Sbjct 732 ACCATGAGCGCTGCTCAGATAGCGATGGTCTGGCCCCTCCTCAGCATCTTATCCGAGTGG 791

Query 541 AAGGAAATTTGCGTGTGGAGTATTTGGATGAC-AAACACTTTTCGACATAGTGTGGTGG 598

|||||||||||||||||||||||||||||||| |||||||||||||||||||||||||||

Sbjct 792 AAGGAAATTTGCGTGTGGAGTATTTGGATGACAGAAACACTTTTCGACATAGTGTGGTGG 851

Query 599 TGCCCTATGAGCCGCCTGAGGTTGGCTCTGACTGTACCACCATCCACTACAACTACATGT 658

||||||||||||||||||||||||||||||||||||||||||||||||||||||||||||||||||

Sbjct 852 TGCCCTATGAGCCGCCTGAGGTTGGCTCTGACTGTACCACCATCCACTACAACTACATGT 911

Query 659GTAACAGTTCCTGCATGGGCGGCATGAACCGGAGGCCCATCCTCACCATCATCACACTGG 718

||||||||||||||||||||||||||||||||||||||||||||||||||||||||||||||||

Sbjct 912 GTAACAGTTCCTGCATGGGCGGCATGAACCGGAGGCCCATCCTCACCATCATCACACTGG 971

Query 719 AAGACTCCAGTGGTAATCTACTGGGACGGAACAGCTTTGAGGTGCGTGTTTGTGCCTGTC 778

|||||||||||||||||||||||||||||||||||||||||||||||||||||||||||||||||| 
Sbjct 972 AAGACTCCAGTGGTAATCTACTGGGACGGAACAGCTTTGAGGTGCGTGTTTGTGCCTGTC 1031

Query 779CTGGGAGAGACCGGCGCACAGAGGAAGAGAATCTCCGCAAGAAAGGGGAGCCTCACCACG 838

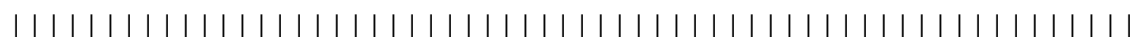

Sbjct 1032 CTGGGAGAGACCGGCGCACAGAGGAAGAGAATCTCCGCAAGAAAGGGGAGCCTCACCACG 1091

Query 839 AGCTGCCCCCAGGGAGCACTAAGCGAGCACTGCCCAACAACAYCAGCTCCTCTCCCCAGC 898

|||||||||||||||||||||||||||||||||||||||||||| ||||||||||||||||||

Sbjct 1092 AGCTGCCCCCAGGGAGCACTAAGCGAGCACTGCCCAACAACACCAGCTCCTCTCCCCAGC 1151

Appendix C.2 List of Changes to the Data Bank Sequence

Codon 72: CCC changes to CGC: Prolin to Arginine a common polymorphism.

Codon 209 AGA: A and G deleted. DELETION causes FRAMESHIFT, truncated protein occurs DNA binding domain involved. This mutation is identical with the one described as p.R209fs*6 (Deletion-Frameshift) in the COSMIC (Catalogue of Somatic Mutations in Cancer) database. The mutated genotype is also mentioned in Reference [37].

Western blot detection of p53 protein in protein lysate of SCC-25 cells using the mouse monoclonal DO-7 antibody. Detroit 562 cell lysates, with a known gain of function mutation were used as a positive control.

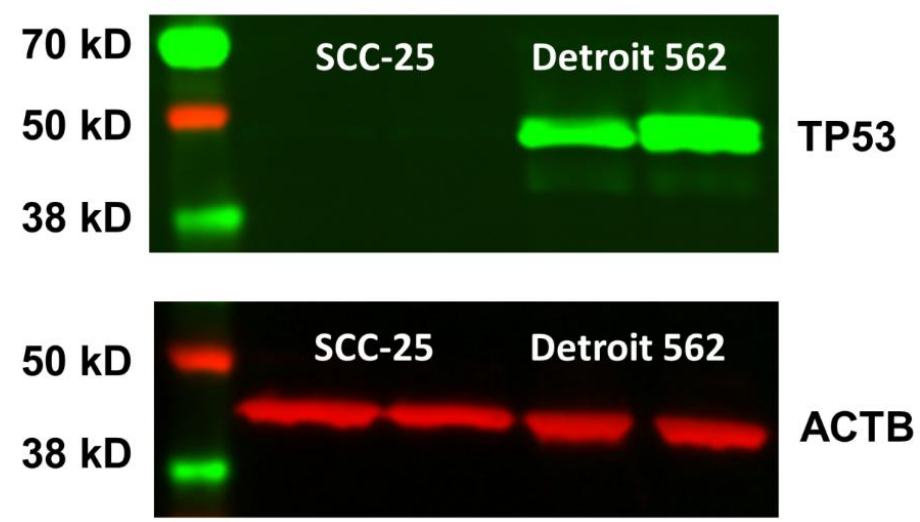

Figure A2. Western blot of p53 protein (green) in SCC-25 and Detroit 562 cells, beta-actin (red) (ACTB) was used as loading control. Protein signal were detected by near infrared fluorescence.

SCC- 25 cells contain very week, almost not visible band of p53 protein, while Detroit 562 cells synthesize strongly detectable protein. The p.R209fs* 6 mutant protein product might be unstable and it degrades in the SCC-25 cells. As loading control: $\beta$-actin was used.

\section{References}

1. Nelson, K.B.; Grether, J.K.; Croen, L.A.; Dambrosia, J.M.; Dickens, B.F.; Jelliffe, L.L.; Hansen, R.L.; Phillips, T.M. Neuropeptides and neurotrophins in neonatal blood of children with autism or mental retardation. Ann. Neurol. 2001, 49, 597-606. [CrossRef] [PubMed]

2. Sen, S.; Duman, R.; Sanacora, G. Serum brain-derived neurotrophic factor, depression, and antidepressant medications: Meta-analyses and implications. Biol. Psychiatry 2008, 64, 527-532. [CrossRef] [PubMed] 
3. Yu, Y.B.; Zuo, X.L.; Zhao, Q.J.; Chen, F.X.; Yang, J.; Dong, Y.Y.; Wang, P.; Li, Y.Q. Brain-derived neurotrophic factor contributes to abdominal pain in irritable bowel syndrome. Gut 2012, 61, 685-694. [CrossRef] [PubMed]

4. Kaye, D.M.; Vaddadi, G.; Gruskin, S.L.; Du, X.J.; Esler, M.D. Reduced myocardial nerve growth factor expression in human and experimental heart failure. Circ. Res. 2000, 86, E80-E84. [CrossRef] [PubMed]

5. Luongo, L.; Maione, S.; Di Marzo, V. Endocannabinoids and neuropathic pain: Focus on neuron-glia and endocannabinoid-neurotrophin interactions. Eur. J. Neurosci. 2014, 39, 401-408. [CrossRef] [PubMed]

6. Hempstead, B.L.; Schleifer, L.S.; Chao, M.V. Expression of functional nerve growth factor receptors after gene transfer. Science 1989, 243, 373-375. [CrossRef] [PubMed]

7. Rodriguez-Tebar, A.; Dechant, G.; Barde, Y.A. Binding of brain-derived neurotrophic factor to the nerve growth factor receptor. Neuron 1990, 4, 487-492. [CrossRef]

8. Verge, V.M.; Merlio, J.P.; Grondin, J.; Ernfors, P.; Persson, H.; Riopelle, R.J.; Hokfelt, T.; Richardson, P.M. Colocalization of NGF binding sites, trk mRNA, and low-affinity NGF receptor mRNA in primary sensory neurons: Responses to injury and infusion of NGF. J. Neurosci. 1992, 12, 4011-4022. [CrossRef] [PubMed]

9. Squinto, S.P.; Stitt, T.N.; Aldrich, T.H.; Davis, S.; Bianco, S.M.; Radziejewski, C.; Glass, D.J.; Masiakowski, P.; Furth, M.E.; Valenzuela, D.M.; et al. trkB encodes a functional receptor for brain-derived neurotrophic factor and neurotrophin-3 but not nerve growth factor. Cell 1991, 65, 885-893. [CrossRef]

10. Lamballe, F.; Klein, R.; Barbacid, M. trkC, a new member of the trk family of tyrosine protein kinases, is a receptor for neurotrophin-3. Cell 1991, 66, 967-979. [CrossRef]

11. Roh, J.; Muelleman, T.; Tawfik, O.; Thomas, S.M. Perineural growth in head and neck squamous cell carcinoma: A review. Oral Oncol. 2015, 51, 16-23. [CrossRef] [PubMed]

12. Ng, Y.K.; Wong, E.Y.; Lau, C.P.; Chan, J.P.; Wong, S.C.; Chan, A.S.; Kwan, M.P.; Tsao, S.W.; Tsang, C.M.; Lai, P.B.; et al. K252a induces anoikis-sensitization with suppression of cellular migration in Epstein-Barr virus (EBV)—Associated nasopharyngeal carcinoma cells. Investig. New Drugs 2012, 30, 48-58. [CrossRef] [PubMed]

13. Dudas, J.; Bitsche, M.; Schartinger, V.; Falkeis, C.; Sprinzl, G.M.; Riechelmann, H. Fibroblasts produce brain-derived neurotrophic factor and induce mesenchymal transition of oral tumor cells. Oral Oncol. 2011, 47, 98-103. [CrossRef] [PubMed]

14. Dudas, J.; Fullar, A.; Bitsche, M.; Schartinger, V.; Kovalszky, I.; Sprinzl, G.M.; Riechelmann, H. Tumor-produced, active interleukin-1beta regulates gene expression in carcinoma-associated fibroblasts. Exp. Cell Res. 2011, 317, 2222-2229. [CrossRef] [PubMed]

15. Dudas, J.; Fullar, A.; Romani, A.; Pritz, C.; Kovalszky, I.; Hans Schartinger, V.; Mathias Sprinzl, G.; Riechelmann, H. Curcumin targets fibroblast-tumor cell interactions in oral squamous cell carcinoma. Exp. Cell Res. 2013, 319, 800-809. [CrossRef] [PubMed]

16. Kupferman, M.E.; Jiffar, T.; El-Naggar, A.; Yilmaz, T.; Zhou, G.; Xie, T.; Feng, L.; Wang, J.; Holsinger, F.C.; $\mathrm{Yu}, \mathrm{D}$; ; et al. TrkB induces EMT and has a key role in invasion of head and neck squamous cell carcinoma. Oncogene 2010, 29, 2047-2059. [CrossRef] [PubMed]

17. Hayashi, K.; Karatsaidis, A.; Schreurs, O.; Bjornland, T.; Sugisaki, M.; Schenck, K. NGF and its receptors TrkA and p75NTR in the epithelium of oral lichen. J. Oral Pathol. Med. 2008, 37, 241-248. [CrossRef] [PubMed]

18. Yamaguchi, T.; Okumura, T.; Hirano, K.; Watanabe, T.; Nagata, T.; Shimada, Y.; Tsukada, K. p75 neurotrophin receptor expression is a characteristic of the mitotically quiescent cancer stem cell population present in esophageal squamous cell carcinoma. Int. J. Oncol. 2016, 48, 1943-1954. [CrossRef] [PubMed]

19. Chakravarthy, R.; Mnich, K.; Gorman, A.M. Nerve growth factor (NGF)-mediated regulation of p75(NTR) expression contributes to chemotherapeutic resistance in triple negative breast cancer cells. Biochem. Biophys. Res. Commun. 2016, 478, 1541-1547. [CrossRef] [PubMed]

20. Marynka-Kalmani, K.; Treves, S.; Yafee, M.; Rachima, H.; Gafni, Y.; Cohen, M.A.; Pitaru, S. The lamina propria of adult human oral mucosa harbors a novel stem cell population. Stem Cells 2010, 28, 984-995. [CrossRef] [PubMed]

21. Tomellini, E.; Lagadec, C.; Polakowska, R.; Le Bourhis, X. Role of p75 neurotrophin receptor in stem cell biology: More than just a marker. Cell. Mol. Life Sci. 2014, 71, 2467-2481. [CrossRef] [PubMed]

22. Soland, T.M.; Brusevold, I.J.; Koppang, H.S.; Schenck, K.; Bryne, M. Nerve growth factor receptor (p75 NTR) and pattern of invasion predict poor prognosis in oral squamous cell carcinoma. Histopathology 2008, 53, 62-72. [CrossRef] [PubMed] 
23. Verbeke, S.; Meignan, S.; Lagadec, C.; Germain, E.; Hondermarck, H.; Adriaenssens, E.; Le Bourhis, X. Overexpression of p75(NTR) increases survival of breast cancer cells through p21(waf1). Cell Signal. 2010, 22, 1864-1873. [CrossRef] [PubMed]

24. Saleh, K.; Eid, R.; Haddad, F.G.; Khalife-Saleh, N.; Kourie, H.R. New developments in the management of head and neck cancer-Impact of pembrolizumab. Ther. Clin. Risk Manag. 2018, 14, 295-303. [CrossRef] [PubMed]

25. Gottgens, E.L.; Ostheimer, C.; Bussink, J.; Span, P.N.; Hammond, E. HPV, hypoxia and radiation response in head and neck cancer. Br. J. Radiol. 2018, 20180047. [CrossRef]

26. Salazar, C.R.; Smith, R.V.; Garg, M.K.; Haigentz, M., Jr.; Schiff, B.A.; Kawachi, N.; Anayannis, N.; Belbin, T.J.; Prystowsky, M.B.; Burk, R.D.; et al. Human papillomavirus-associated head and neck squamous cell carcinoma survival: A comparison by tumor site and initial treatment. Head Neck Pathol. 2014, 8, 77-87. [CrossRef] [PubMed]

27. Othumpangat, S.; Gibson, L.F.; Samsell, L.; Piedimonte, G. NGF is an essential survival factor for bronchial epithelial cells during respiratory syncytial virus infection. PLoS ONE 2009, 4, e6444. [CrossRef] [PubMed]

28. Kofler, B.; Borena, W.; Manzl, C.; Dudas, J.; Wegscheider, A.S.; Jansen-Durr, P.; Schartinger, V.; Riechelmann, H. Sensitivity of tumor surface brushings to detect human papilloma virus DNA in head and neck cancer. Oral Oncol. 2017, 67, 103-108. [CrossRef] [PubMed]

29. Rheinwald, J.G.; Beckett, M.A. Tumorigenic keratinocyte lines requiring anchorage and fibroblast support cultured from human squamous cell carcinomas. Cancer Res. 1981, 41, 1657-1663. [PubMed]

30. Chen, Y.W.; Lin, G.J.; Chia, W.T.; Lin, C.K.; Chuang, Y.P.; Sytwu, H.K. Triptolide exerts anti-tumor effect on oral cancer and KB cells in vitro and in vivo. Oral Oncol. 2009, 45, 562-568. [CrossRef] [PubMed]

31. Sinha, U.K.; Schorn, V.J.; Hochstim, C.; Chinn, S.B.; Zhu, S.; Masood, R. Increased radiation sensitivity of head and neck squamous cell carcinoma with sphingosine kinase 1 inhibition. Head Neck 2011, 33, 178-188. [CrossRef] [PubMed]

32. Steinbichler, T.B.; Metzler, V.; Pritz, C.; Riechelmann, H.; Dudas, J. Tumor-associated fibroblast-conditioned medium induces CDDP resistance in HNSCC cells. Oncotarget 2016, 7, 2508-2518. [CrossRef] [PubMed]

33. Steinbichler, T.B.; Alshaimaa, A.; Maria, M.V.; Daniel, D.; Herbert, R.; Jozsef, D.; Ira-Ida, S. Epithelial-mesenchymal crosstalk induces radioresistance in HNSCC cells. Oncotarget 2018, 9, 3641-3652. [CrossRef] [PubMed]

34. Sano, D.; Xie, T.X.; Ow, T.J.; Zhao, M.; Pickering, C.R.; Zhou, G.; Sandulache, V.C.; Wheeler, D.A.; Gibbs, R.A.; Caulin, C.; et al. Disruptive TP53 mutation is associated with aggressive disease characteristics in an orthotopic murine model of oral tongue cancer. Clin. Cancer Res. 2011, 17, 6658-6670. [CrossRef] [PubMed]

35. Peterson, W.D., Jr.; Stulberg, C.S.; Simpson, W.F. A permanent heteroploid human cell line with type B glucose-6-phosphate dehydrogenase. Proc. Soc. Exp. Biol. Med. 1971, 136, 1187-1191. [CrossRef] [PubMed]

36. Peterson, W.D., Jr.; Stulberg, C.S.; Swanborg, N.K.; Robinson, A.R. Glucose-6-phosphate dehydrogenase isoenzymes in human cell cultures determined by sucrose-agar gel and cellulose acetate zymograms. Proc. Soc. Exp. Biol. Med. 1968, 128, 772-776. [CrossRef] [PubMed]

37. Martin, D.; Abba, M.C.; Molinolo, A.A.; Vitale-Cross, L.; Wang, Z.; Zaida, M.; Delic, N.C.; Samuels, Y.; Lyons, J.G.; Gutkind, J.S. The head and neck cancer cell oncogenome: A platform for the development of precision molecular therapies. Oncotarget 2014, 5, 8906-8923. [CrossRef] [PubMed]

38. Ferris, R.L.; Martinez, I.; Sirianni, N.; Wang, J.; Lopez-Albaitero, A.; Gollin, S.M.; Johnson, J.T.; Khan, S. Human papillomavirus-16 associated squamous cell carcinoma of the head and neck (SCCHN): A natural disease model provides insights into viral carcinogenesis. Eur. J. Cancer 2005, 41, 807-815. [CrossRef] [PubMed]

39. Bouchalova, P.; Nenutil, R.; Muller, P.; Hrstka, R.; Appleyard, M.V.; Murray, K.; Jordan, L.B.; Purdie, C.A.; Quinlan, P.; Thompson, A.M.; et al. Mutant p53 accumulation in human breast cancer is not an intrinsic property or dependent on structural or functional disruption but is regulated by exogenous stress and receptor status. J. Pathol. 2014, 233, 238-246. [CrossRef] [PubMed]

40. Hicks, J.K.; Chute, C.L.; Paulsen, M.T.; Ragland, R.L.; Howlett, N.G.; Gueranger, Q.; Glover, T.W.; Canman, C.E. Differential roles for DNA polymerases eta, zeta, and REV1 in lesion bypass of intrastrand versus interstrand DNA cross-links. Mol. Cell Biol. 2010, 30, 1217-1230. [CrossRef] [PubMed] 
41. Gonzalez-Nicolini, V.; Fux, C.; Fussenegger, M. A novel mammalian cell-based approach for the discovery of anticancer drugs with reduced cytotoxicity on non-dividing cells. Investig. New Drugs 2004, 22, 253-262. [CrossRef] [PubMed]

42. Draper, B.K.; Komurasaki, T.; Davidson, M.K.; Nanney, L.B. Epiregulin is more potent than EGF or TGFalpha in promoting in vitro wound closure due to enhanced ERK/MAPK activation. J. Cell. Biochem. 2003, 89, 1126-1137. [CrossRef] [PubMed]

43. Metzler, V.M.; Pritz, C.; Riml, A.; Romani, A.; Tuertscher, R.; Steinbichler, T.; Dejaco, D.; Riechelmann, H.; Dudas, J. Separation of cell survival, growth, migration, and mesenchymal transdifferentiation effects of fibroblast secretome on tumor cells of head and neck squamous cell carcinoma. Tumour Biol. 2017, 39, 1010428317705507. [CrossRef] [PubMed]

44. Van der Heijden, M.S.; Brody, J.R.; Dezentje, D.A.; Gallmeier, E.; Cunningham, S.C.; Swartz, M.J.; DeMarzo, A.M.; Offerhaus, G.J.; Isacoff, W.H.; Hruban, R.H.; et al. In vivo therapeutic responses contingent on Fanconi anemia/BRCA2 status of the tumor. Clin. Cancer Res. 2005, 11, 7508-7515. [CrossRef] [PubMed]

45. Seaborn, T.; Ravni, A.; Au, R.; Chow, B.K.; Fournier, A.; Wurtz, O.; Vaudry, H.; Eiden, L.E.; Vaudry, D. Induction of serpinb1a by PACAP or NGF is required for PC12 cells survival after serum withdrawal. J. Neurochem. 2014, 131, 21-32. [CrossRef] [PubMed]

46. Kitamura, T.; Tange, T.; Terasawa, T.; Chiba, S.; Kuwaki, T.; Miyagawa, K.; Piao, Y.F.; Miyazono, K.; Urabe, A.; Takaku, F. Establishment and characterization of a unique human cell line that proliferates dependently on GM-CSF, IL-3, or erythropoietin. J. Cell Physiol. 1989, 140, 323-334. [CrossRef] [PubMed]

47. Anand, P.; Foley, P.; Navsaria, H.A.; Sinicropi, D.; Williams-Chestnut, R.E.; Leigh, I.M. Nerve growth factor levels in cultured human skin cells: Effect of gestation and viral transformation. Neurosci. Lett. 1995, 184, 157-160. [CrossRef]

48. Fox, A.J.; Patel, H.J.; Barnes, P.J.; Belvisi, M.G. Release of nerve growth factor by human pulmonary epithelial cells: Role in airway inflammatory diseases. Eur. J. Pharmacol. 2001, 424, 159-162. [CrossRef]

49. Festuccia, C.; Muzi, P.; Gravina, G.L.; Millimaggi, D.; Speca, S.; Dolo, V.; Ricevuto, E.; Vicentini, C.; Bologna, M. Tyrosine kinase inhibitor CEP-701 blocks the NTRK1/NGF receptor and limits the invasive capability of prostate cancer cells in vitro. Int. J. Oncol. 2007, 30, 193-200. [CrossRef] [PubMed]

50. Bronzetti, E.; Artico, M.; Forte, F.; Pagliarella, G.; Felici, L.M.; D’Ambrosio, A.; Vespasiani, G.; Bronzetti, B. A possible role of BDNF in prostate cancer detection. Oncol. Rep. 2008, 19, 969-974. [CrossRef] [PubMed]

51. Huang, Y.T.; Lai, P.C.; Wu, C.C.; Hsu, S.H.; Cheng, C.C.; Lan, Y.F.; Chiu, T.H. BDNF mediated TrkB activation is a survival signal for transitional cell carcinoma cells. Int. J. Oncol. 2010, 36, 1469-1476. [PubMed]

52. Dolle, L.; El Yazidi-Belkoura, I.; Adriaenssens, E.; Nurcombe, V.; Hondermarck, H. Nerve growth factor overexpression and autocrine loop in breast cancer cells. Oncogene 2003, 22, 5592-55601. [CrossRef] [PubMed]

53. Dalal, R.; Djakiew, D. Molecular characterization of neurotrophin expression and the corresponding tropomyosin receptor kinases (trks) in epithelial and stromal cells of the human prostate. Mol. Cell. Endocrinol. 1997, 134, 15-22. [CrossRef]

54. Johnson Chacko, L.; Blumer, M.J.F.; Pechriggl, E.; Rask-Andersen, H.; Dietl, W.; Haim, A.; Fritsch, H.; Glueckert, R.; Dudas, J.; Schrott-Fischer, A. Role of BDNF and neurotrophic receptors in human inner ear development. Cell Tissue Res. 2017, 370, 347-363. [CrossRef] [PubMed]

55. Choi, S.J.; Choi, Y.I.; Kim, L.; Park, I.S.; Han, J.Y.; Kim, J.M.; Chu, Y.C. Preparation of compact agarose cell blocks from the residues of liquid-based cytology samples. Korean J. Pathol. 2014, 48, 351-360. [CrossRef] [PubMed]

(C) 2018 by the authors. Licensee MDPI, Basel, Switzerland. This article is an open access article distributed under the terms and conditions of the Creative Commons Attribution (CC BY) license (http:/ / creativecommons.org/licenses/by/4.0/). 